

\section{STUDIA UNIVERSITATIS HEREDITATI}

Znanstvena revija za raziskave in teorijo kulturne dediščine

Letnik 5 , številka 2, 2017

Studia universitatis hereditati je humanistična znanstvena revija za raziskave in teorijo kulturne dediščine z mednarodnim uredniškim odborom. Objavlja znanstvene in strokovne članke s širšega področja kulturne dediščine (arheologija, arhitektura, etnologija, jezikoslovje, literarna, kulturna, glasbena, intelektualna, religijska, vojaška zgodovina, zgodovina idej itn.) in pregledne članke ter recenzije tako domačih kot tujih monografij z omenjenih področij. Revija izhaja dvakrat letno. Izdajata jo Fakulteta za bumanistične studije (Oddelek za arheologijo in dediscino) in Založba Univerze na Primorskem.

Poglavitni namen revije je prispevati k razvoju raziskav kulturne dediščine v najširšem in k topoglednemu interdisciplinarnemu pristopu $\mathrm{k}$ teoretičnim in praktičnim raziskovalnim vprašanjem. Tako revija posebno pozornost namenja razvoju slovenske znanstvene in strokovne terminologije, konceptov in paradigem na področju raziskovanja kulturne dediščine v okviru humanističnih ved.

\section{Glauni in odgovorni urednik}

dr. Gregor Pobežin (Fakulteta za humanistične študije Univerze na Primorskem, Koper)

Urednici stevilke

dr. Zrinka Mileusnić in dr. Alenka Tomaž (Fakulteta za humanistične študije Univerze na Primorskem, Koper) Tehnična ureditev revije, oblikovanje in prelom

dr. Jonatan Vinkler (Fakulteta za humanistične študije Univerze na Primorskem, Koper)

Lektor (slovenska besedila)

Davorin Dukič (Univerza na Primorskem, Koper)

\section{Uredniski odbor}

dr. Zdravka Hincak (Filozofski fakultet, Sveučilište u Zagrebu), dr. Matej Hriberšek (Filozofska fakulteta, Univerza v Ljubljani), dr. Katja Hrobat Virloget (Fakulteta za humanistične študije Univerze na Primorskem, Koper), dr. Irena Lazar (Fakulteta za humanistične študije Univerze na Primorskem, Koper), dr. Maša Sakara Sučevič (Pokrajinski muzej, Koper), dr. Alenka Tomaž (Fakulteta za humanistične študije Univerze na Primorskem, Koper), dr. Tomislav Vignjevič (Fakulteta za humanistične študije Univerze na Primorskem, Koper), dr. Jonatan Vinkler (Fakulteta za humanistične študije Univerze na Primorskem, Koper), dr. Paola Visentini (Museo Friulano di Storia Naturale, Udine)

Izdajatelj: Univerza na Primorskem - Založba Univerze na Primorskem (za Fakulteto za humanistične študije Univerze na Primorskem)

(C) 2017 Založba Univerze na Primorskem

Zanjo: prof. dr. Dragan Marušič, rektor

Titov $\operatorname{trg} 4$

SI-6000 Koper

ISSN $2350-5443$

DOI: https://doi.org/10.26493/2350-5443.5(2)

\section{(c) (i) $\circledast$}


studia universitatis hereditati 



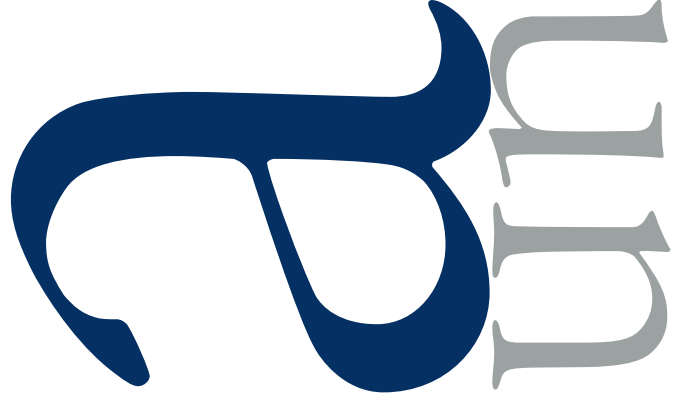

○
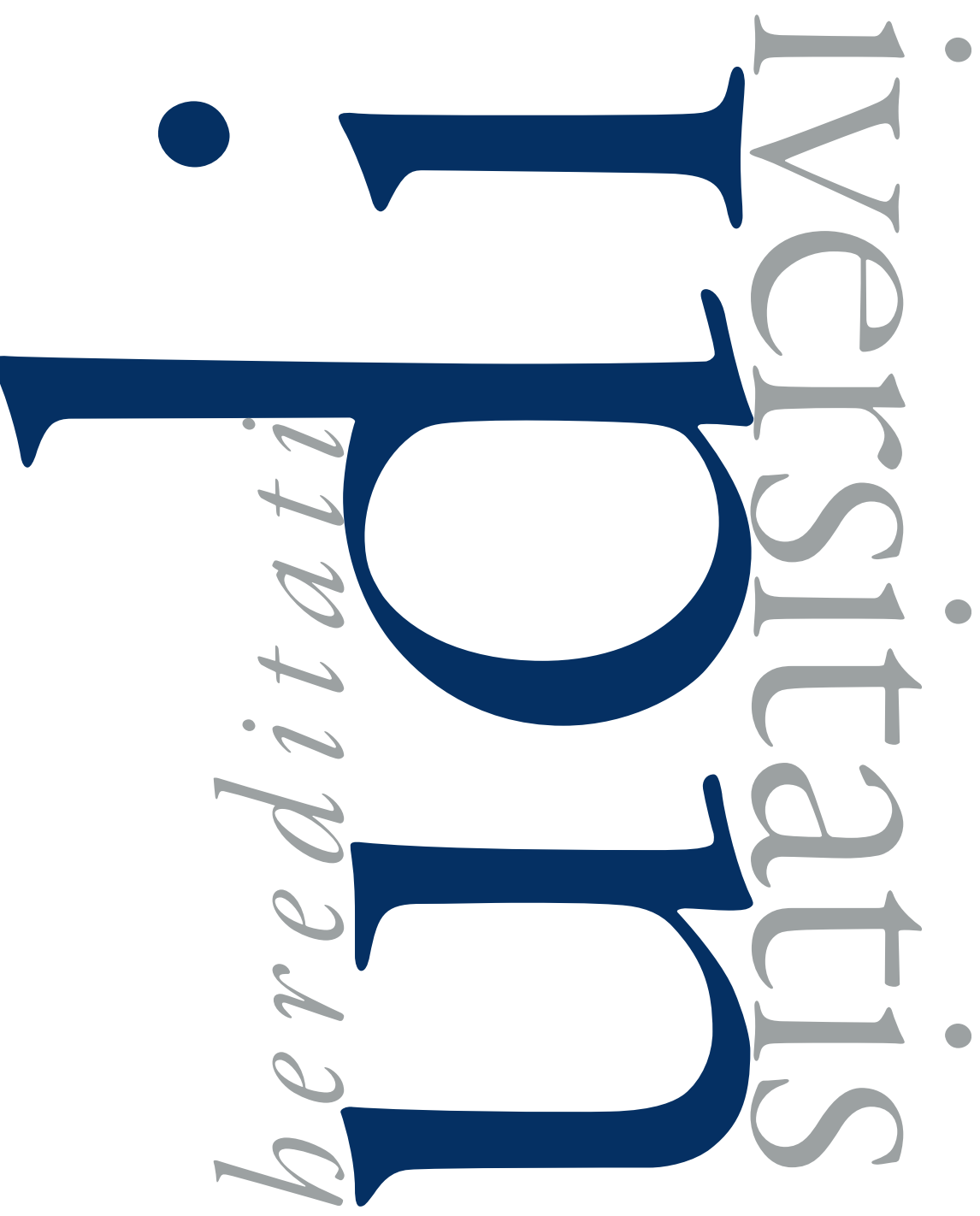

LETNIK 5

ŠTEVILKA 2

LETO 2017
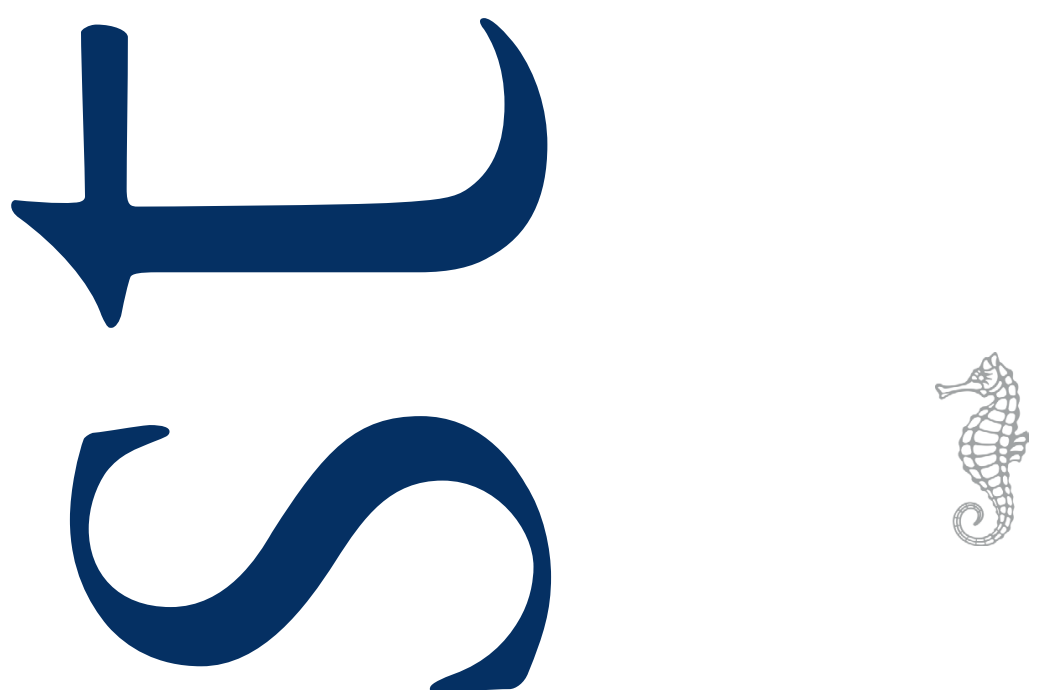
-

r

$\downarrow$

G

1

-

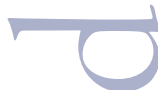

( )

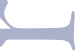

(U)

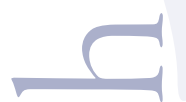




\section{Vsebina/Contents}

Julijana Visocnik, Bernarda Zupanek, Simona Jarc in Luka Gale

9 Rimski fragmenti z napisi v Mestnem muzeju Ljubljana

Jadranka Cergol

2 I I cambiamenti etnici sulla penisola Italica dalla guerra sociale alla morte dell'imperatore Augusto

Miba Mlinar

37 Rimski grob z zrcalcem z Lipičarjevega vrta na Mostu na Soči

Zdravka Hincak in Kresimir Filipec

47 Forensics and Archaeology: The Ethical Approach to Graves Excavation and Research Zorana Dimković

59 Nevidljiva dugovečnost u arheološkom kontekstu

Alenka Tomazin Maśa Sakara Sućevic

7I Arheološke raziskave na lokaciji Kaštelir nad Kortamiv letu 2014

Nenad Joncić

IOI Implementation of 3 D Scanning in Presentationand Preservation of Cultural Heritage Case Study: Dungeons of the National Museum in Pančevo 
-

r

$\downarrow$

G

1

-

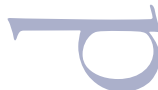

( )

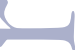

(U)

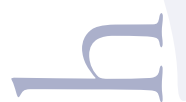




\title{
Arheološke raziskave na lokaciji Kaštelir nad Kortami v letu 2014
}

\author{
Alenka Tomaž, Fakulteta za humanistične študije, Univerza na Primorskem, Koper \\ Maša Sakara Sučević, Pokrajinski muzej Koper
}

Kaštelir nad Kortami pri Izoli je ena od najbolje poznanih prazgodovinskih naselbin v slovenskem delu Istre. Najdišče je prvi omenjal že Pietro Coppo v i6. stoletju, na začetku 20. stoletja ga je Carlo Marchesetti označil kot Il castelliere d'Albuzzano presso Corte d'Isola, prve sistematične arheološke raziskave pa so potekale v 60 -ih in 70 -ih letih 20. stoletja. Z njimi je bil tudi prvič potrjen izjemen pomen najdišča kot prazgodovinskega kaštelirja. Med leti 2008 and 2014 je arheološka lokacija Kaštelir nad Kortami postal glavni poudarek projekta „Kaštelir nad Kortami - Kulturno-rekreacijski part“, ki ga je finančno podpirala Občina Izola, izvajali pa raziskovalci Univerze na Primorskem. V članku prikazujemo rezultate arheološkega testnega sondiranja, izvedenega v letu 20I4, ki kažejo na to, da je Kaštelir nad Kortami potrebno razumeti ne samo kot prazgodovinsko naselbinsko točko ampak tudi kot prostor zelo zgodnje rimske poselitve.

Ključne besede: Kaštelir nad Kortami, prazgodovinsko gradišče, rimska poselitev, Istra

Kaštelir above Korte near Izola is one of the best known prehistoric settlements in the Slovenian part of Istria. The site was first mentioned by Pietro Coppo in the $16{ }^{\text {th }}$ Century, at the beginning of $20^{\text {th }}$ Century Carlo Marchesetti described the site as Il castelliere d'Albuzzano presso Corte d'Isola, however the first proper archaeological excavation took place in the 60's and $70^{\prime}$ 's of $20^{\text {th }}$ Century. With it the site was confirmed as a prehistoric hillfort of exceptional importance. Between 2008 and 2014 Kaštelir has been a main focus of the project "Kaštelir above Korte - Cultural and recreational park", financially supported by the Municipality of Izola and conducted by research team from University of Primorska. In article we are presenting results of the archaeological test probing, done in 20I4, which demonstrates that Kaštelir above Korte must be considered not only as a prehistoric settlement but also a place of a very early Roman settlement.

Key words: Kaštelir above Korte, prehistoric hillfort, roman settlement, Istra

$\mathrm{K}$ aštelir nad Kortami pri Izoli velja za eno večjih prazgodovinskih naselbin $\mathrm{v}$ slovmorske višine tik nad vasjo Korte na južni vzpetini grebena, ki se vleče od Kort do Malije. Sam vrh Kaštelirja je, geomorfološko gledano, obsežna planota ovalne oblike, vsem poznano arheološko najdišče pa leži na vzdolžni vzpetini s položnimi pobočji na vzhodni in strmim pad- cem na severni strani. Sledi obodne arhitekture prazgodovinskega gradišča/kaštelirja so sicer še dobro vidni, vendar na več mestih povsem preraščeni z neprehodnim rastjem (sl. I).

Med leti 2008-2014 je potekal projekt Kaštelir nad Kortami - Kulturno rekreacijski park, ki ga je ob podpori Občine Izola izvajal Inštitut za dediščino Sredozemlja Znanstveno-ra- 


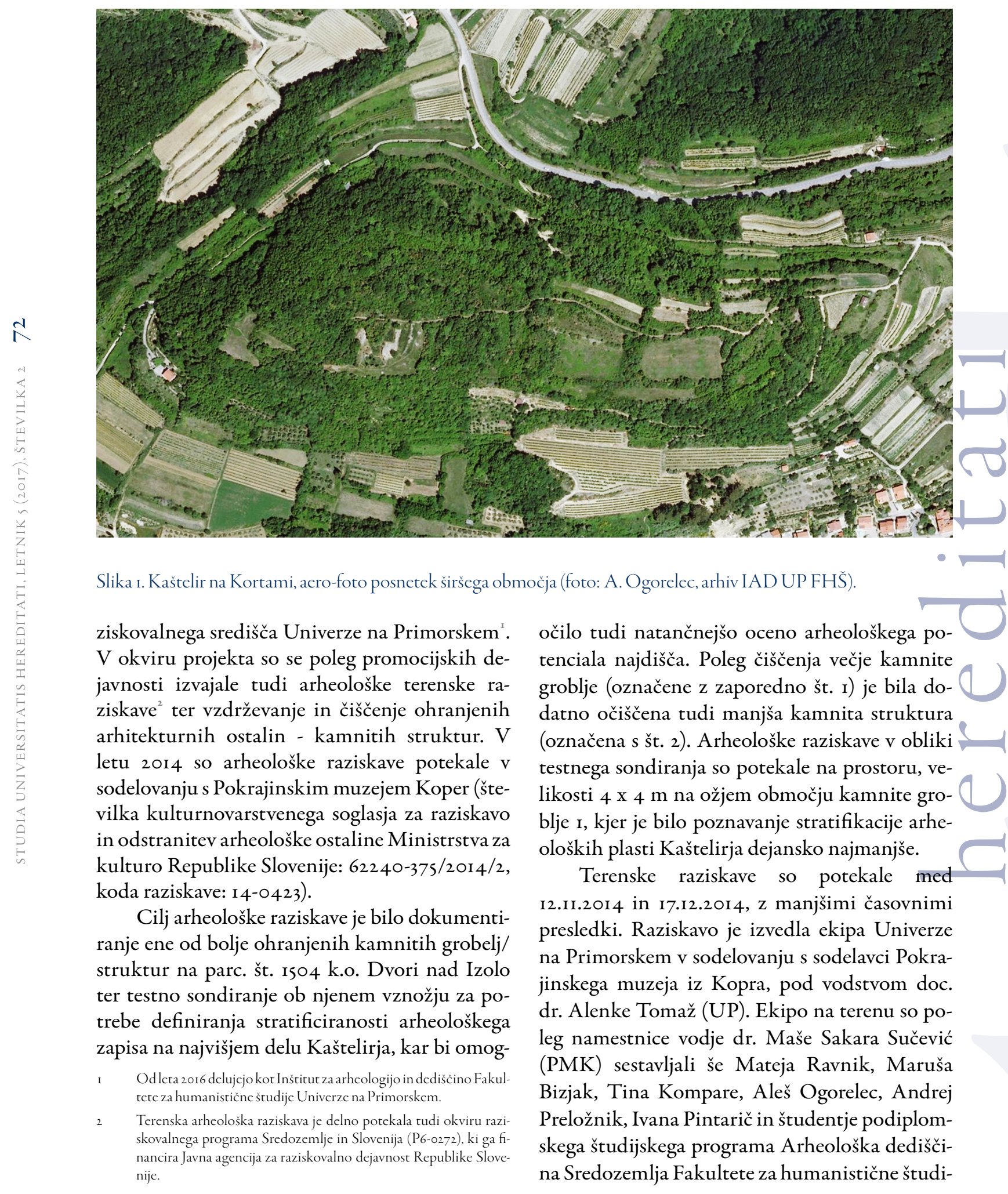




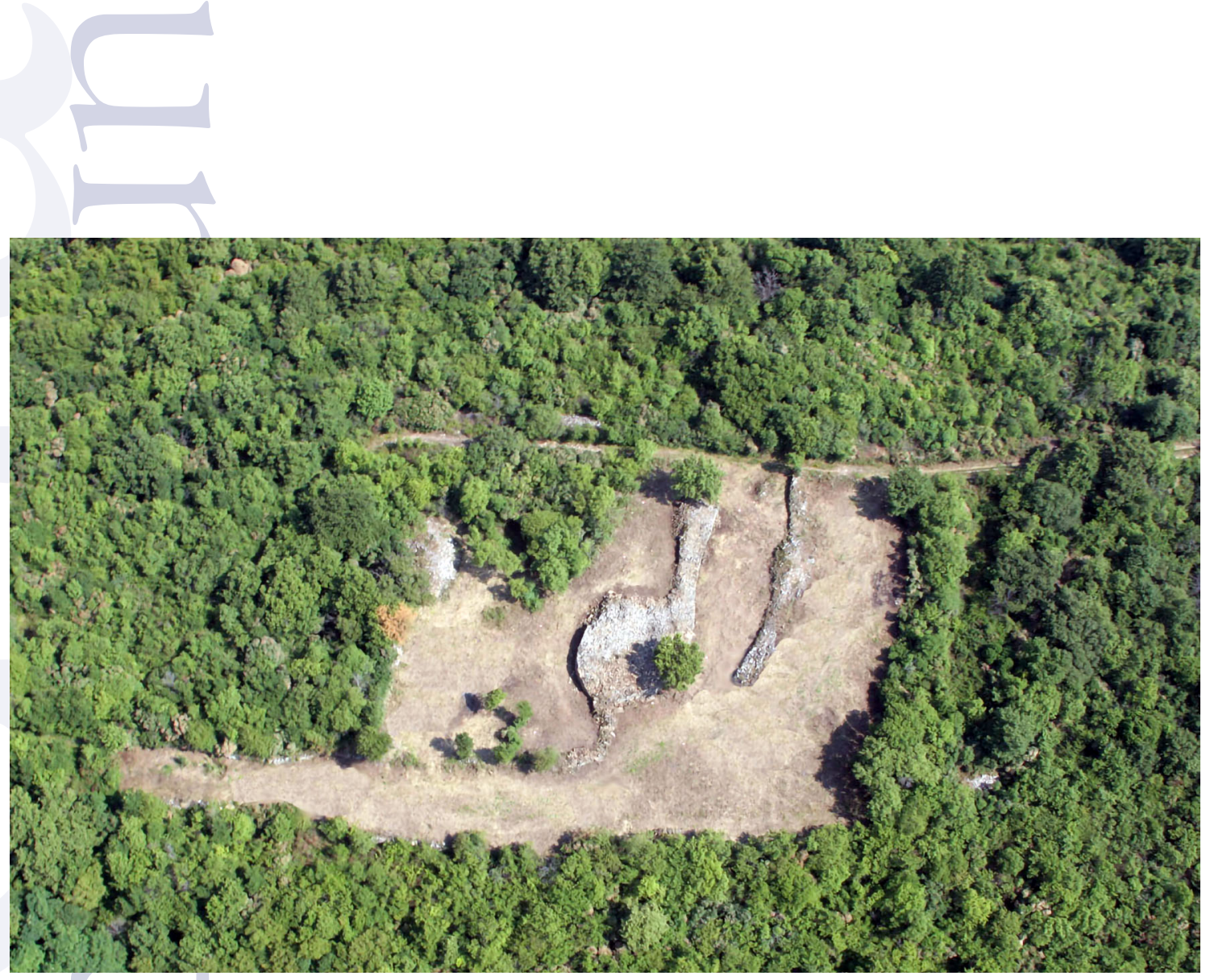

Slika 2. Kaštelir na Kortami, aero-foto posnetek očiščenih kamnitih struktur v letu 2009 (foto: A. Ogorelec, arhiv IAD UP FHŠ).

je Univerze na Primorskem, Valentin Babuder, Aleksander Močibob in Peter Šuler.

\section{Kaštelir nad Kortami - kratka zgodovina arheoloških raziskav}

Zgodovina raziskav Kaštelirja nad Kortami je bila ob več priložnostih že nadrobno predstavljena tudi širši javnosti ${ }^{3}$, zato na tem mestu navajamo le najpomembnejše poudarke iz relativno dolge zgodovine raziskav najdišča.

Najstarejša omemba najdišča sodi v i6. stoletje. Pietro Coppo omenja Kaštelir z imenom Albucan, kot starodavno prebivališče Izolčanov in sicer, da gre za enega najvišjih hribov v notranjosti Istre, na pol poti do Grožnjana. Grki naj bi kraj poimenovali Vrano Casto (oz. Vrano Cas-

\footnotetext{
Maša Sakara Sučević, Prazgodovinska keramika med Miljskim zalivom in porečjem Mirne, (Fakulteta za humanistične študije, Univerza na Primorskem, doktorska disertacija - neobjavljena, 2012); Alenka Tomaž in Maša Sakara Sučević, Kaśtelir nad Kortami - historična analiza prostora (elaborat) (Koper: Inštitut za dediščino Sredozemlja, Znanstveno-raziskovalno središče, Univerza na Primorskem, 2014).
}

tro, tudi Castro - Uranion), Latinci Castelaerio oz. Castel Celeste oz. Castru Arium, v vulgarnem jeziku pa naj bi mu rekli Castelir (Kaštelir) ${ }^{4}$. Hrib Albucan omenja tudi G. Thamar leta I58I. D. Fortunato Olmo pa leta I885 navede vsa antična poimenovanja, ki se razlikujejo od poimenovanj Pietra Coppa le s podatkom o poimenovanju Argonautov, ki naj bi ga imenovali Vranio.

Carlo Marchesetti je Kaštelir opisal kot Il castelliere d'Albuzzano presso Corte d'Isola. Obenem je podal načrt gradišča z obodnim in dvema prečnima nasipoma ter omenil, da je bila pred kakšnim letom (torej okrog leta 1900) tu najdena, danes izgubljena, bronasta sulična ost: bella lancia di bronzo $0^{6}$.

4 Sakara Sučević, Prazgodovinska keramika med Miljskim zalivom in porečjem Mirne.

$5 \quad$ Ime Albuzan se med italijansko govorečim prebivalstvom ohrani vsaj še do druge svetovne vojne, kot kažejo napisi na škatlah v depoju PMK iz leta 1941.

6 Carlo Marchesetti, I castellieripreistorici di Trieste e della regione Giulia (Trieste: Museo civico di Storia naturale, 1903), 74, t. 9: f. I. 

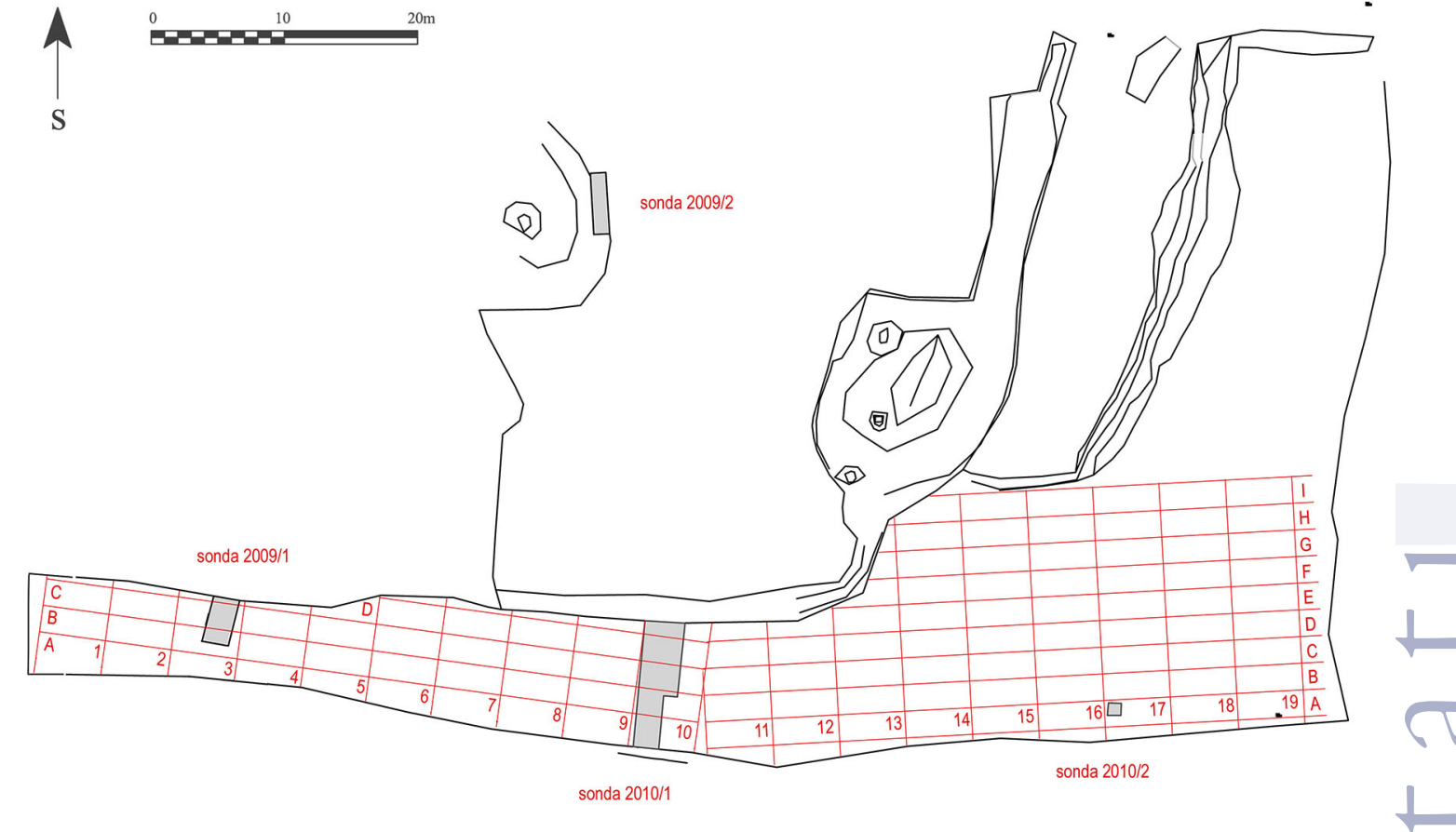

Slika 3. Kaštelir na Kortami, raziskave 2008-2010, območje ekstenzivnega pregleda z prostorsko razdelitvijo zbiralnih enot in lokacija sonde (pripravil A. Ogorelec, arhiv IAD UP FHŠ).

Prva sondiranja na vrhu in na pobočjih Kaštelirja je leta 1956 izvedla kustodinja tedanjega Mestnega muzeja Piran Elica Boltin-Tome. Pri tem je našla bronasto zapestnico rombičnega preseka, ploščat prstan s presegajočimi konci ter lok bronaste certoške fibule, več kosov žlindre in manjše kose hišnega lepa iz železne dobe. Med ostanki rimske materialne kulture pa dele amfor, opek, železne žeblje s polkrožno odebeljeno glavico 7 . Leta 1957 so v celoti izkopali, že v prejšnjem letu deloma izkopan rimski grob z oljenko, posodjem, stekleničkami in od ognja poškodovani bronasti strigilis z deli bronaste posodice ${ }^{8} . \mathrm{Z}$ arheološkimi zaščitnimi in raziskovalnimi izkopavanji je Boltin-Tome nadaljevala tudi v letih 1960 in $1962 \mathrm{z}$ večjo sondo na srednjem prečnem nasipu, da bi ugotovila tehnike gradnje in čas nastanka nasipa. Glavni del prazgodovinske nasel-

7 Elica Boltin, "Arheološke najdbe na Kaštelirju nad Kortami," Arheološki vestnik 9-10/3-4 (1958-59): 237; Elica Boltin, "Kaštelir nad Kortami," Varstvo spomenikov 7 (1958-59): 279. 293.

bine naj bi bil, glede na vse dotedanje raziskave, na zahodnem delu gradišča. Skladno s to ugotovitvijo je severni prerez prečnega nasipa pokazal, da je zahodni del nasipa bolje ohranjen od vzhodnega ${ }^{9}$. Detajlna analiza in reinterpretacija izsledkov raziskav Elice Boltin Tome je nadrobno predstavljena že drugje ${ }^{\mathrm{IO}}$, zato je na tem mestu ne bomo ponovno obnavljali.

Med leti 2008-20Io so potekale na območju Kaštelirja raziskovalne dejavnosti v sklopu delovanja Inštituta za dediščino Sredozemlja UP. Leta 2008 je potekalo čiščenje parcel (odstranitev rastja), čiščenje kamnitih struktur in foto-dokumentiranje stanja na parceli št. 1706 in I705 k.o. Dvori nad Izolo (sl. 2).

V letu 2009 je bilo v okviru študijske prakse (UP FHŠ OAD) izvedeno dokumentiranje (opisno, fotografsko) ohranjenosti kamnitih struktur po celotnem Kaštelirju, izkopani sta

\footnotetext{
Sakara Sučevič, Prazgodovinska keramika med Miljskim zalivom in porečjem Mirne.

Sakara Sučevič, Prazgodovinska keramika med Miljskim zalivom in porečjem Mirne.
} 


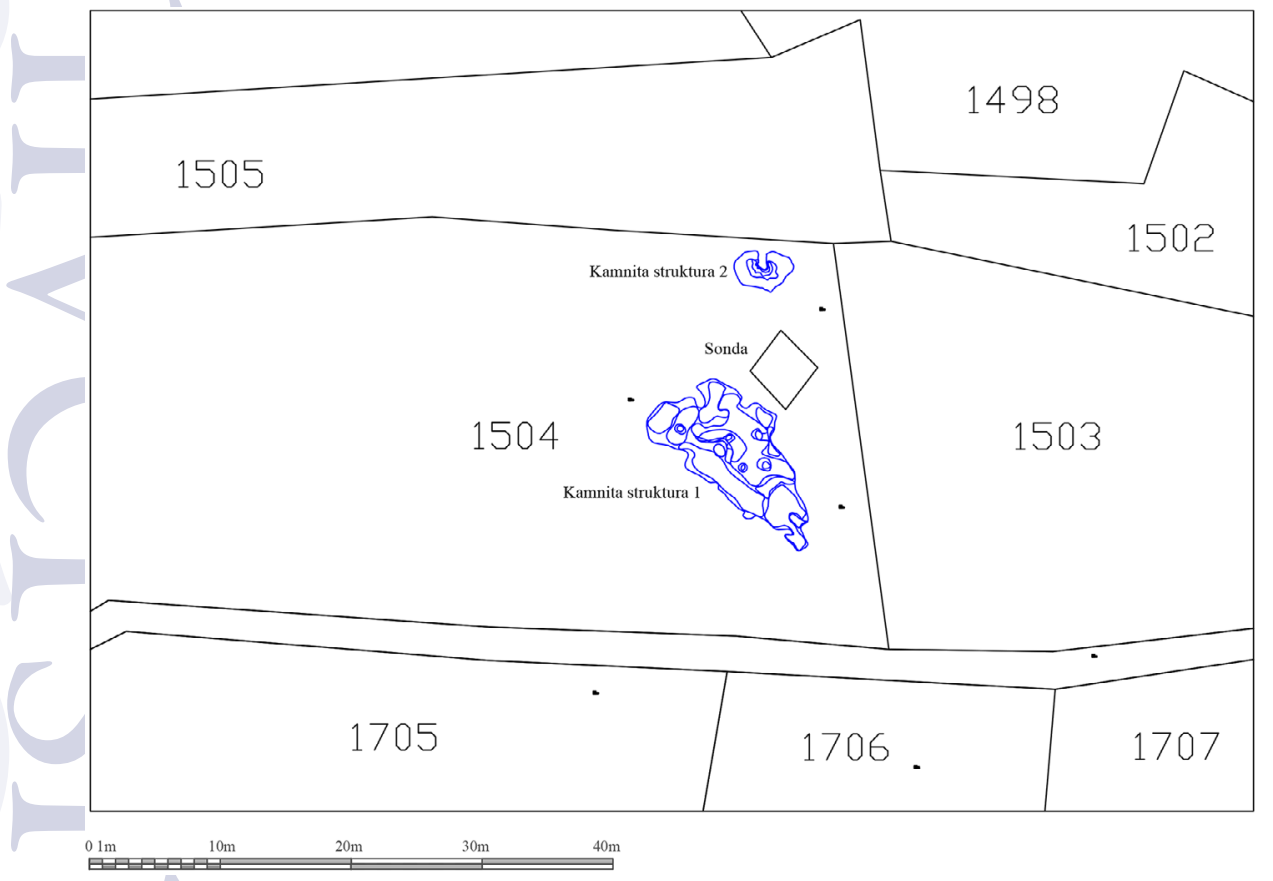

Slika 4. Kaštelir na Kortami, lokacije arheološke testne sonde, kamnite strukture/groblje I in kamnite strukture $2 \mathrm{v}$ katastrskem načrtu (pripravil A. Ogorelec, arhiv IAD UP FHŠ).

bili tudi dve testni sondi pod vodstvom Maše Sakara Sučević (UP IDS). Sonda I/2009 na mestu divjega vkopa $\mathrm{v}$ zahodnem delu parcele 1706 k.o. Dvori nad Izolo in sonda $2 / 2009$ ob vznožju gomile 2 na parceli 1705 k.o. Dvori nad Izolo. V letu 2010 pa je bil izveden ekstenzivni površinski pregled na južnem delu parcele 1706 k.o. Dvori nad Izolo, v obsegu $100 \mathrm{x}$ Io metrov in zbiralnih enotah enote $5 \times 2 \mathrm{~m}$ ter zaščitne terenske raziskave v obliki sondiranja (sl. 3 ).

Sonda v velikosti cca. 3 x $10 \mathrm{~m}$ je potekala prečno na rob terase. Izkopavanja so na dan prinesla številno prazgodovinsko in rimskodobno keramiko in bronasto figurico psa, bronasto fibulo srednjelatenske sheme in jantarno jagodo $^{\text {II }}$. Stratigrafikacija plasti je pokazala, da je bilo najdišče uničeno že ob prvem terasiranju, ki naj bi se zgodilo v začetku 20. stol. Le na južnem delu sonde, kjer teren strmo pada, se je ohrani-

I I Maša Sakara Sučević, Andrej Preložnik in Aleš Ogorelec, Preliminarno poročilo o zascitnih arheoloskih raziskavah na Kastelirju nad Kortami, parc. śt. I706, k.o. Dvori nad Izolo 2.4.-21.4.2010, (Koper: UP ZRS IDS, 2010). lo domnevno tlakovanje in nekaj jam za stojke, ki pa jih ni bilo moč datirati. Vse ostale plasti so vsebovale premešano gradivo ${ }^{12}$.

\section{Rezultati arheološkega testnega sondiranja v letu 2014}

Arheološke raziskave v letu 2014 so se izvajale na območju Korte - arheološko najdišče Kaštelir pri Čedljah (EŠD 7238), v obliki arheološkega testnega sondiranja $\mathrm{z}$ namenom preverbe stratifikacije ohranjenega arheološkega zapisa na najvišjem platoju nekdanje prazgodovinske naselbine. Sonda, v velikosti 4 × $4 \mathrm{~m}$, je bila zakoličena na parc. št. I504, k.o. Dvori nad Izolo, tik ob vznožju kamnite strukture I (groblje) (sl. 4), kar naj bi omogočilo boljši vpogled v stratificiranost arheološkega depozita na tem delu Kaštelirja, hkrati pa omogočilo podrobnejšo oceno arheološkega potenciala najdišča.

I2 Maša Sakara Sučević, Andrej Preložnik in Aleš Ogorelec, Preliminarno poročilo o zaščitnih arheoloških raziskavah na Kaštelirju nad Kortami, parc. št. 1706, k.o. Dvori nad Izolo 2.4.-21.4.2010 (Koper: UP ZRS IDS, 2010). 
Območje, izbrano za testno sondiranje, v preteklosti ni bilo podvrženo intenzivni kmetijski dejavnosti, zato je bilo pričakovati, da bo na tem delu arheološki zapis ohranjen najbolj celostno. Sondiranje je potekalo na ožjem območju kamnite strukture I, kjer je bilo dosedanje poznavanje stratifikacije arheoloških plasti Kaštelirja dejansko tudi najmanjše. Izkopno polje je bilo locirano severno od poti, ki vodi vzdolžno po Kaštelirju. Območje sonde je bilo pred našim posegom zaraščeno z nižjimi drevesi, podrastjo in zatravljeno.

Sondo smo locirali ob severovzhodni, še vidni rob kamnite strukture I. S pomočjo analize stratifikacije plasti ob vznožju kamnite strukture smo želeli pridobiti boljši vpogled v relativni stratigrafski odnos med še vidno kamnito strukturo in evidentiranimi arheološkimi plastmi, kar bi lahko pripomoglo $\mathrm{k}$ pojasnjevanju nastanka omenjene kamnite strukture, kakor tudi njeni časovni opredelitvi.

Sonda je bila postavljena na poševno območje, tik ob vidnemu robu kamnite strukture, katero se je končalo z manjšo kotanjo na njenem severnem delu. Samo površje območja sonde je bilo pred posegom neravno, kar je kazalo na to, da se pod površjem tudi na tem delu najverjetneje nahajajo plasti kamenja in lomljencev. Pri postavitvi sonde se je bilo potrebno prilagajati $\check{s}$ e rastju in večjim, vidnim kamnitim ploščam, zato ni imela povsem pravokotne oblike. Sonda je bila razdeljena v štiri kvadrante, velikosti 2 x 2 m, označeme od kv. I - do kv. 4.

\section{Metodologija in potek raziskave}

Metodologija terenskih raziskav je bila pogojena s standardi arheoloških raziskav, predvidenimi za testna sondiranja ${ }^{13}$, se pravi, stratigrafsko so se odstranjevale arheološke plasti in zemljina, grajene arheološke ostaline pa so se ohranjale »in situ«. Ker so se v jugozahodnem delu sonde elementi kamnite strukture 1 pojavili že tik pod travnato rušo, smo jih na tem delu obranjali nedotaknjene. $\mathrm{V}$ dogovoru s konservatorjem smo v kamnito strukturo I posegli le na zahodnem

I3 Pravilnik o arheoloških raziskavah (Ur.l. RS, št. 3/2013). delu sonde $\mathrm{v}$ skupni širini $\mathrm{I}, 3 \mathrm{~m}$, $\mathrm{z}$ namenom preverbe njene notranje zgradbe in pa stratifikacije plasti pod samo kamnito strukturo. Dokumentacija je obsegala postopke (geodetsko, fotografsko in opisno dokumentiranje evidentiranih plasti in arheoloških ostalin), ki so predvideni s strokovnimi standardi arheoloških raziskav.

\section{Stratifikacija plasti in arheološke ostaline na območju sonde}

Arheološke raziskave smo pričeli z odstranjevanjem travnate ruše (SE I), ki je bila tanka, do o,os cm debela, temno rjava plast glinenega melja, prekoreninjena, sestavljena iz preperela humusa s številnim rastjem. Plast je vsebovala odlomke rimskodobne keramike in recentne predmete. Pod travnato rušo smo v južnem delu sonde evidentirali elemente kamnite strukture I, v severnem delu pa smo naleteli na stratifikacijo plasti, ki so se odložile tik ob njej.

Elementi kamnite strukture I so obsegali dve zgostitvi kamenja, sestavljeni iz večjih kamnitih plošč in lomljencev peščenjaka velikosti od $30 \times 20 \mathrm{~cm}$ do $130 \times 60 \mathrm{~cm}$ (označeni kot SE 2). Prva zgostitev kamenja v obliki pasu se je nahajala na sredini sonde $\mathrm{v}$ širini $\mathrm{I}, 30 \mathrm{~m}$, druga pa ob severnem robu izkopnega polja sonde v velikosti I X I,I m. Kamni so ležali tesno skupaj in so bili interpretirani kot zunanji venec kamnite strukture I. Južno od te zgostitve je ležala plast kamnov in lomljencev peščenjaka velikosti od Io x Io do 15 X 20 cm, označena s SE 4. Kamenje je ležalo v zgornjem delu pobočja v širini I, $6 \mathrm{~m}$. Prostor med kamni je bil zapolnjen $\mathrm{z}$ rjavo glineno meljasto, humusno prstjo, ki je bila podobna SE 3 (sl. s).

Kamnita struktura i je ležala na rimskodobni plasti SE 16, katera je evidentirana kot plast temno rjavega glinenega melja, ki je vsebovala odlomke rimskodobne keramike, redke odlomke prazgodovinske keramike, kosti, školjke in redek gradbeni material. Plast je vsebovala tudi precej kamenja manjših dimenzij, peščenjaka in fliša nepravilnih in pravilnih oblik, nekateri med njimi so nekateri tudi ožgani. Plast lahko označimo za ruševinsko plast z več kamenja. Pod 


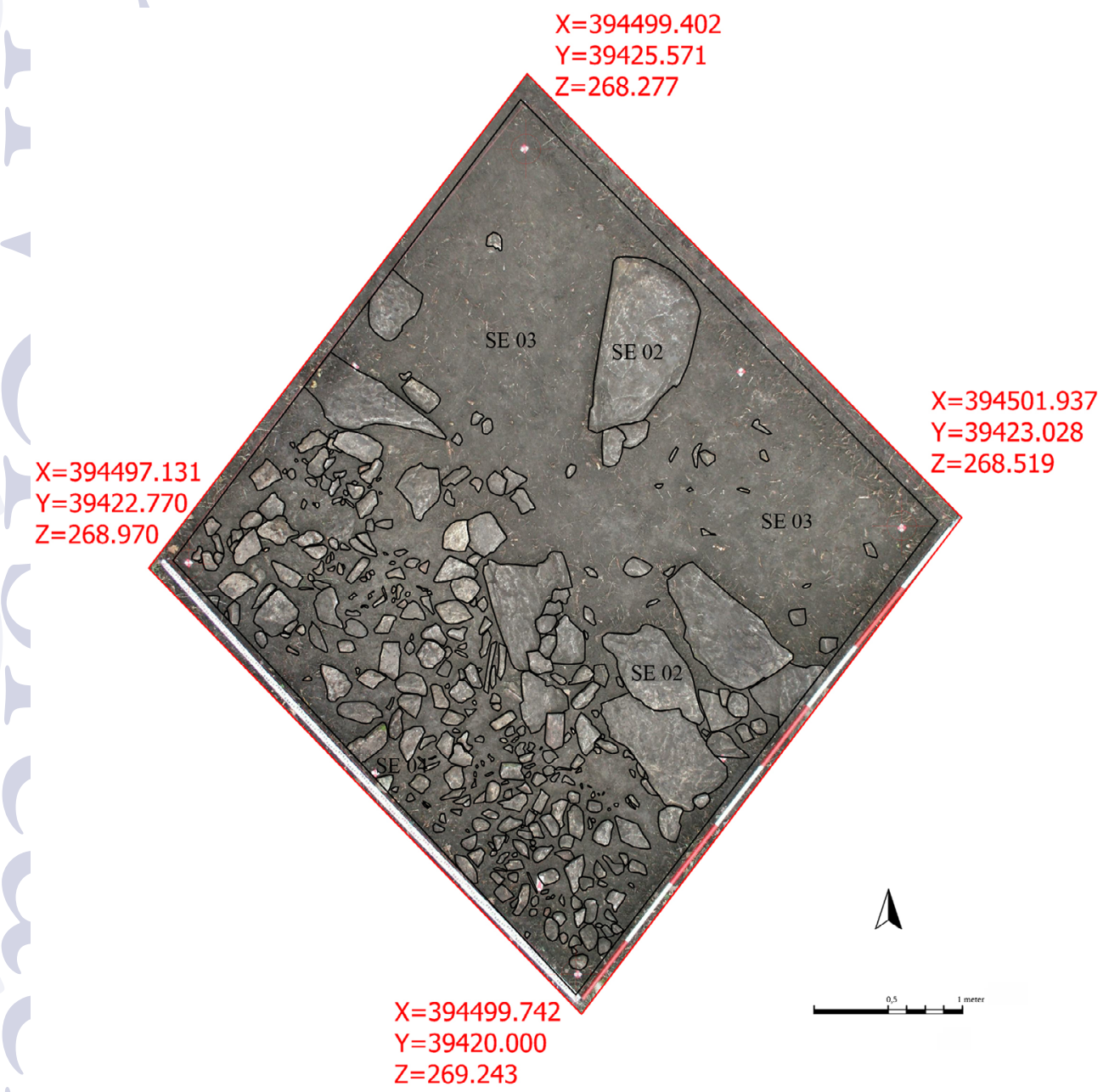

Slika s. Kaštelir na Kortami, sonda I, georeferenciran kompozitni foto-tloris plasti in arheoloških ostalin po odstranitvi travnate ruše (foto: A. Ogorelec, arhiv IAD UP FHŠ).

njo je ležala rimskodobna plast (SE i 4), sestavljena iz zelo temno sivega glinenega melja, ki je vseboval veliko količino sicer močno razdrobljene rimskodobne keramike, nekaj odlomkov prazgodovinske keramike, kosti, školjke ter kamnito kocko, kamnit izvrtek in 3 odlomke kamnitih žrmelj (sl. 6). Plast SE I4 se je nahajala po celotnem raziskanem delu sonde, tudi v njenem severozahodnem delu in je ležala neposredno na geološki osnovi ( $S E$ I5). Kamni peščenjaka v plasti SE 14 so po večini velikosti do 8 x 5 $\mathrm{cm}$. Manj kamenja je bilo v severnem delu plasti, več pa v bližini obeh kamnitih grobelj $\mathrm{SE}_{4}$ in
I2. V plasti je bila odkita izjemna količina polžev in manj školjk. Material v severozahodnem delu sonde bolj razdrobljen (odlomki do $2 \mathrm{~cm}$ pogostejši). Plast je bila debela do o,15 m. Plast lahko interpretiramo kot ostalino rimskodobne kulturne plasti.

V severovzhodnem delu sonde je pod travnato rušo ( $\mathrm{SE}$ I) po celotni širini sonde ležala rjava plast glinenega melja, prekoreninjena, humusna in gnetljiva, označena s SE 3. Plast je vsebovala rimskodobne odlomke keramike, odlomke rimskodobnega gradbenega materiala, kosti, školjke, odlomek brusa in manjše kepe ožgane gline. De- 


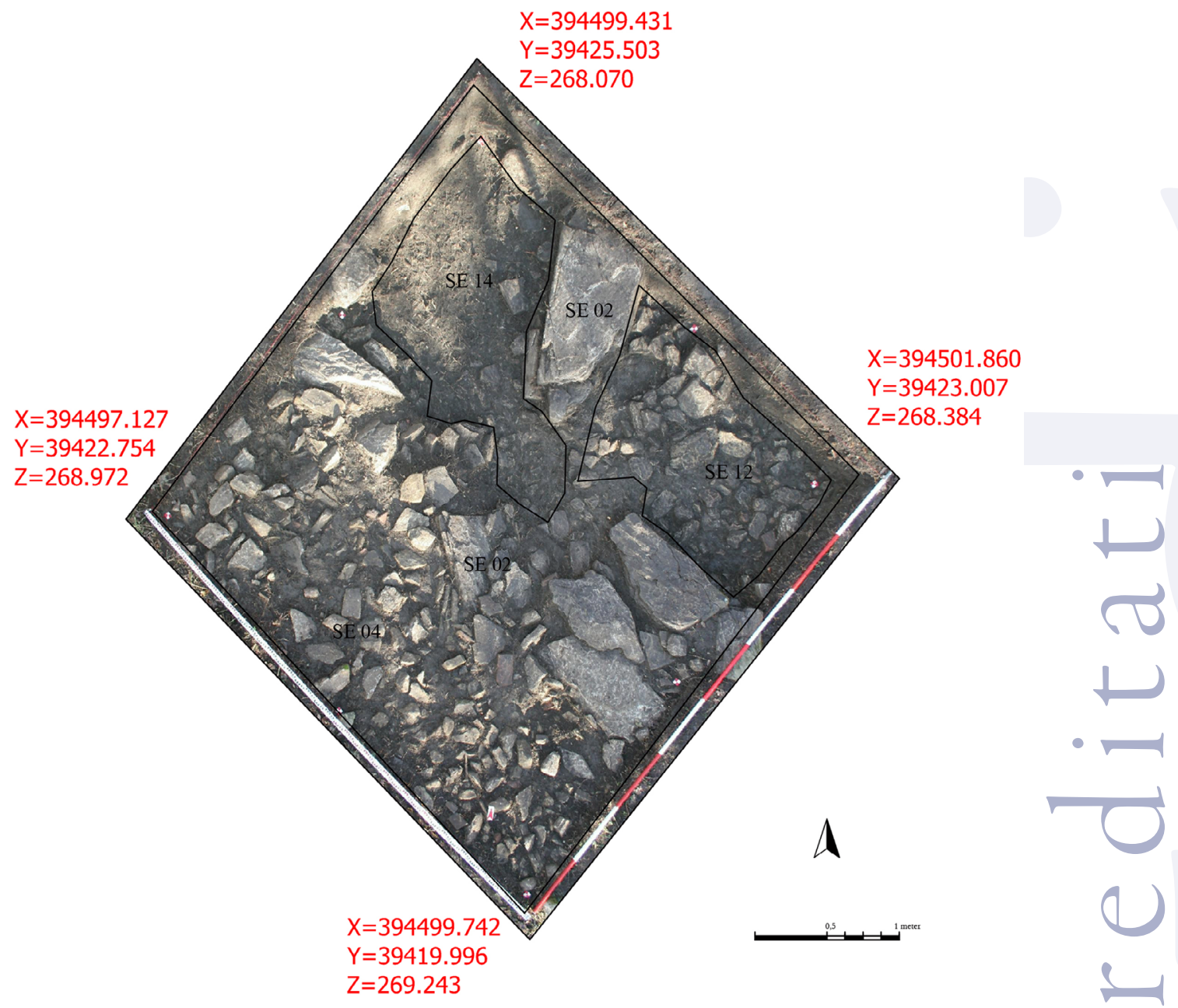

Slika 6. Kaštelir na Kortami, sonda I, georeferenciran kompozitni foto-tloris rimskodobne plasti SE 14 in arheoloških ostalin kamnite strukture I (foto: A. Ogorelec, arhiv IAD UP FHŠ).

belina plasti je znašala $0,08 \mathrm{~m}$. Odložila se je le v tem delu sonde v širini I, $5 \mathrm{~m}$. Pod njo se je v severovzhodnem delu nahajala plast SE I2, plast temno rjavega glinenega melja, ki je vsebovala tudi številno kamenje in lomljence peščenjaka, velikosti do $25 \times 20 \mathrm{~cm}$. Plast ni bila čvrsta, prostor med kamenjem pa je bil zapolnjen s temno rjavo prstjo. Plast kamenja je razčlenjena, manjše zgostitve kamenja pa so se nahajale še zahodno in južno od SE 2. Podobna je bila plasti SE I6, ki smo jo zasledili v jugozahodnem vogalu sonde pod kamnito strukturo. Tudi v tem delu sonde je bilo razvidno da SE 4 leži nad SE I2, obe pa prekrivata kamnite plošče SE 2.

V nasprotnem, severozahodnem delu sonde je pod SE 3 ležala zelo temno sivo rjava plast glinenega melja, debeline do o,Io $\mathrm{m}$ (SE 9), prekoreninjena, ki je vsebovala odlomke rimskodobne keramike in malo školjk. Pod njo je ležala tanka lisasta, zelo temno sivo rjava do sivo rjava plast glinenega melja (SE I3), ki je vsebovala odlomke rimskodobne in redke odlomke prazgodovinske keramike, kamen (brus?), kosti, školjke in en odlomke gradbenega rimskodobnega materiala. Plast SE 13 je ležala nad SE I4, ki 


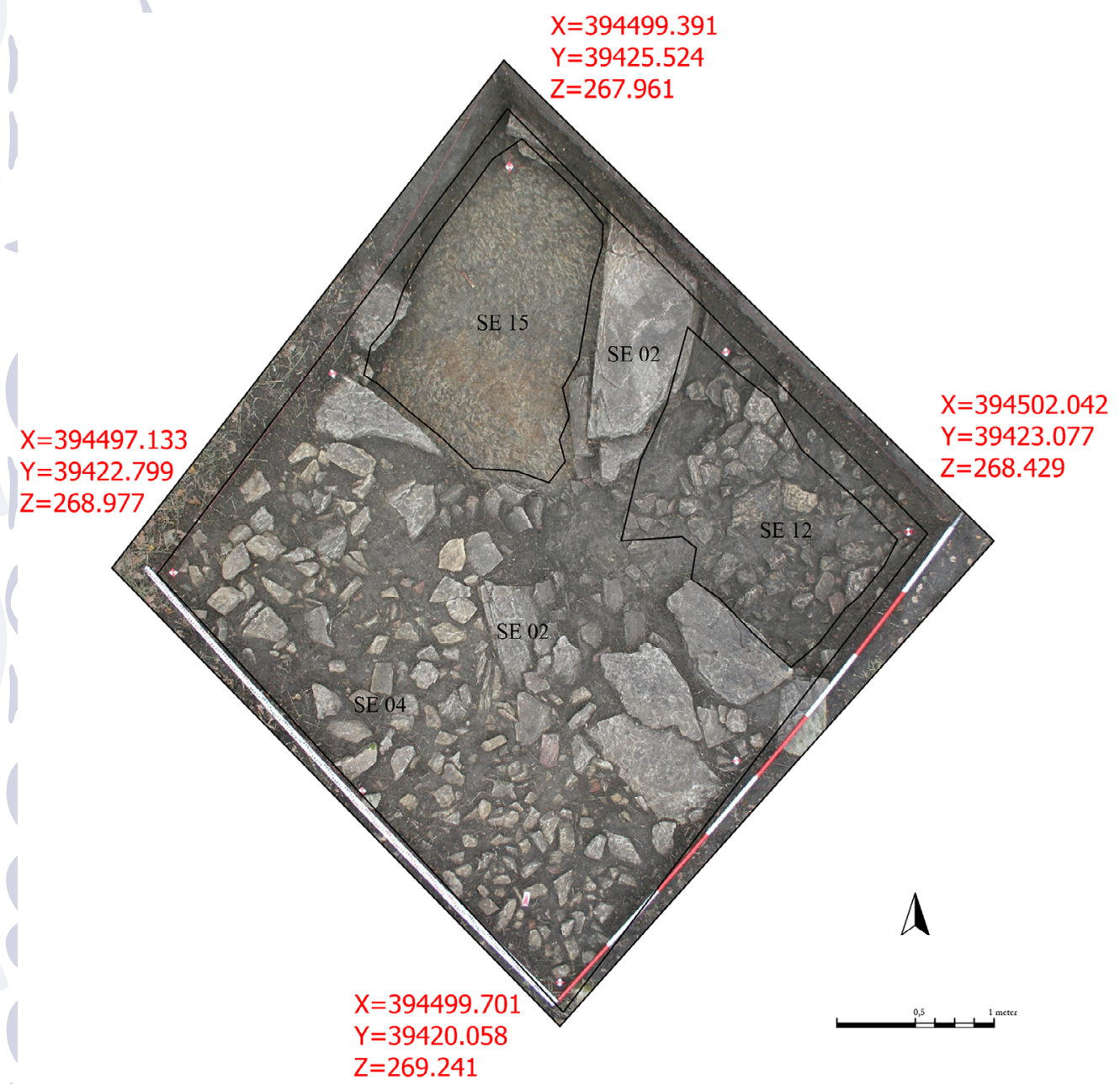

Slika 7. Kaštelir na Kortami, sonda I, georeferenciran kompozitni foto-tloris geološke osnove SE is in arheoloških ostalin kamnite strukture I (foto: A. Ogorelec, arhiv IAD UP FHŠ).

je bila interpretirana kot rimskodobna kulturna plast. Pod SE I4 pa je na celotni raziskani površini ležala SE I5, rumenkast fliš, geološka osnova (sl. 7).V geološko osnovo ni bilo vkopanih nikakršnih jam ali drugih objektov. Na raziskanem delu tudi ni bilo zaslediti intaktnih prazgodovinskih plasti. Prazgodovinske najdbe so se nagajale le v sekundarnih kontekstih.

\section{Arheološko drobno gradivo}

Arheološko gradivo, odkrito pri arheoloških raziskavah testne sonde $\mathrm{I}$, je bilo sicer dokaj številčno, vendar zelo slabo ohranjeno. Gradivo je bilo odkrito v plasteh $\mathrm{SE}_{3}, \mathrm{SE} 5, \mathrm{SE} 8$-10, $\mathrm{SE}_{13}$, SE 16, SE 4/2 in SE I 4. Gradivo je bilo oprano, sortirano in odbrano za katalogizacijo.

Katalog arheološkega drobnega gradiva po posameznih arheoloskih kontekstih

$\mathrm{V}$ katalogu predstavljamo izbor najdb $\mathrm{z}$ arheološkega najdišča Kaštelir nad Kortami, ki obsega 57 odlomkov gradiva, izdelanega iz keramike, kamna, kovine in stekla, ki po večini pripada rimskemu obdobju, nekateri odlomki pa so opredeljeni kot prazgodovinski. 
Opisi keramičnih najdb delno sledijo oblikovno - tehnološkem obrazcu, kot ga je predlagala M. Horvat ${ }^{\mathrm{I} 4}$. Predmeti so predstavljeni opisno, grafično $\mathrm{v}$ fototabelah v merilu $\mathrm{I}: 2$ (sl. 8 - II), del njih pa je bilo tudi izrisanih (sl. I2 - I4). Fotografije in izdelava fototabel je delo Aleša Ogorelca, najdbe je narisala Janja Tratnik Šumi.

Predmeti so v katalogu razporejeni po fazah, katerim pripadajo stratigrafske enote (SE), v katerih so bili najdeni, od najstarejše faze do najmlajše faze. V primeru, da SE vsebuje odlomke različnih obdobij so le-ti znotraj posamezne SE prav tako organizirani kronološko.

Opisi predmetor ${ }^{15} \mathrm{v}$ katalogu vsebujejo najdiščne podatke (SE, kv., začasna inv. št.), podatke o številu odlomkov keramike, obdobju, načinu izdelave, podatke o sestavi lončarske mase, dodelavi in barvi površine (barva določena $s$ pomočjo Munsellove barvne lestvice), načinu žganja, opis okrasa in posebnosti. Rimskodobni odlomki so dodatno opredeljeni še funkcionalno kot fino namizno posodje (tera sigilata), namizno posodje, kuhinjsko posodje in transportno posodje (amfore) ter posebne oblike (predilno vretence). Kovinski, kamniti in stekleni predmeti imajo najdiščne podatke (SE, kv., začasna inv. št.), naveden je material in kratek opis. Vsi predmeti imajo velikost podano $\mathrm{v}$ centimetrih $(\mathrm{cm})$. Za trajno hrambo gradiva je pristojen Pokrajinski muzej Koper.

I. SE I 4, sonda I/20I 4, kv. 4, zač. inv. št.

I $4 / 38$.

Odlomek ostenja prazgodovinske posode, izdelane prostoročno iz drobnozrnate lončarske mase (BCEF). Gladka površina

I4 Milena Horvat, Keramika, Tehnologija keramike, tipologija lončenine, keramični arhiv (Ljubljana: Znanstveni inštitut Filozofske fakultete, 1999)

15 Legenda: Lonćarska masa: zelo finozrnata - zrna so velikosti do o,25 $\mathrm{mm}$; finozrnata - zrna so velikosti $0,26-0,50 \mathrm{~mm}$; drobnozrnata zrna so velikosti od $0,5 \mathrm{I}-2,00 \mathrm{~mm}$, grobozrnata - zrna so velikosti od 2,01-3,00 mm, zelo grobozrnata - zrna so večja od 3,01 mm. Oznake sestavin: A - kremen, $\mathrm{B}$ - kalcijev karbonat, $\mathrm{C}$ - sljuda, D - organske snovi, E - železovi oksidi, F - glinena jedra, G - zdrobljena keramika. Okrajšave: dl. - dolžina, v. - višina, š. - širina, pr. premer, db. - debelina, u. - ustje, d. - dno, nv. - največji, SE - stratigrafska enota, kv. - kvadrant, zač. inv. št. - začasna inventarna številka. je na zunanji strani lisasta rjava $(7.5 \mathrm{YR}$ $5 / 4$ in $\left.7.5 \mathrm{YR}_{5} / 6\right)$, na notranji strani pa sivo črna (7.5YR 3/I). Žganje redukcijsko, verjetno sekundarno žgana. Na ostenju je apliciran okras ščipanega rebra. Dl. 3,4 cm, š. $3,2 \mathrm{~cm}$.

2. SE I 4, sonda I/20I 4, kv. 4, zač. inv. št. I $4 / 40$.

Odlomek ostenja z ročajem prazgodovinske posode, izdelane prostoročno iz grobozrnate lončarske mase (BCF). Gladka površina je lisasta sivo črno temno rjava (7.5 $\mathrm{YR}_{3} / 4$ in $7.5 \mathrm{YR}_{3} / \mathrm{I}$ ). Žganje nepopolno oksidacijsko. Dl. 4,6 $\mathrm{cm}$, š. $4,5 \mathrm{~cm}$, ročaj - š. $3, \mathrm{I} \mathrm{cm}, \mathrm{db}$. I,9 cm.

3. SE I 4 , sonda I/20I 4 , kv. I, zač. inv. št. I $4 /$ I. Fino namizno posodje, odlomek ustja z ostenjem rimskodobne posode, izdelane na lončarskem vretenu iz zelo finozrnate lončarske mase (CE). Gladka, poškodovana površina je rdečkasta (rožnata) (7.5YR 7/4, osnovna površina), • na zunanji in notranji strani ohranjen poškodovan sivo črn premaz $(2.5 \mathrm{Y} 2.5 / \mathrm{I})$ ? Žganje oksidacijsko. Na zunanji in notranji strani vzporedni vodoravni kaneluri. Dl. $2,0 \mathrm{~cm}$, v. $\mathrm{I}, 4 \mathrm{~cm}$.

4. SE I 4, sonda I/20I 4, kv. I, zač. inv. št. I 4/2. Fino namizno posodje, odlomek ustja? $\mathrm{z}$ ostenjem rimskodobne posode, izdelane na lončarskem vretenu iz zelo finozrnate lončarske mase (CE). Gladka, poškodovana površina je rdečkasta (rožnata) (7.5YR 7/4, osnovna površina), na zunanji in notranji strani slabo ohranjen sivo črn premaz (2.5Y 2.5/I). Žganje oksidacijsko. Na notranji? strani vzporedne vodoravni kanelure. Dl. $3,2 \mathrm{~cm}$, v. I,8 cm. Morda del I $4 /$ I.

5. SE I 4 , sonda I/20I 4 , kv. 4, zač. inv. št. I $4 / 35$.

Fino namizno posodje, odlomek roba ustja z ostenjem rimskodobnega krožnika, izdelanega na lončarskem vretenu iz finozrnate lončarske mase (CE). Gladka, delno poškodovana površina je svetlo rdeča 
(7.5YR 7/6, osnovna površina). Na zunanji in notranji strani poškodovan sivo črn premaz (2.5Y 2.5/I). Žganje oksidacijsko. Pr. u. $17,5 \mathrm{~cm}, \mathrm{v}, 2,5 \mathrm{~cm}$.

6. SE I 4 , sonda I/20I 4, kv. I, zač. inv. št. I4/16.

Fino namizno posodje, odlomek ostenja rimskodobne posode, izdelane na lončarskem vretenu iz zelo finozrnate lončarske mase (posamezni fini vključki) (CE). Gladka, poškodovana površina je svetlo rdeča (IOYR 6/6, osnovna površina), na zunanji in notranji strani ohranjen poškodovan sivo črn premaz $(2.5 \mathrm{Y} 2.5 / \mathrm{I})$. Žganje oksidacijsko. Dl. 4,I cm, v. 2,5 cm.

7. SE I 4 , sonda I/2OI 4 , kv. 4, zač. inv. št. I $4 / 36$.

Fino namizno posodje, odlomek ostenja rimskodobne posode, izdelane na lončarskem vretenu iz finozrnate lončarske mase (CE). Gladka, delno poškodovana površina je svetlo rdeča (7.5YR 7/6, osnovna površina). Na zunanji? strani poškodovan sivo črn premaz (7.5Y 2.5/I). Žganje oksidacijsko. Dl. 2, 4 cm, š. I, $8 \mathrm{~cm}$.

8. SE I 4 , sonda I/20I 4, kv. 4, zač. inv. št. I $4 / 37$. Fino namizno posodje, odlomek ostenja rimskodobne posode, izdelane na lončarskem vretenu iz zelo finozrnate lončarske mase (CE). Gladka, delno poškodovana površina je svetlo rdeča (7.5 YR 7/6, osnovna površina). Na zunanji in notranji strani poškodovan sivo črn premaz (2.5YR 2.5/I). Žganje oksidacijsko. Dl. $2,2 \mathrm{~cm}$, š. I, $6 \mathrm{~cm}$.

9. SE I 4 , sonda I/20I 4 , kv. 4, zač. inv. št. I $4 / 33$.

Namizno posodje, odlomek roba ustja z ostenjem rimskodobne čaše, izdelane na lončarskem vretenu z finozrnate lončarske mase (ACF). Gladka površina je sivo črna (2.5Y 2.5/I). Žganje redukcijsko. Pr. u. 7,6 $\mathrm{cm}, \mathrm{v} .1,5 \mathrm{~cm}$.

IO. SE I 4 , sonda I/20I 4 , kv. 4, zač. inv. št. $14 / 34$.
Namizno posodje, odlomek roba ustja z ostenjem rimskodobne čaše, izdelane na lončarskem vretenu iz finozrnate lončarske mase (CF). Gladka površina je svetlo rdeča (7.5YR 6/6). Žganje oksidacijsko. Dl. 3,2 $\mathrm{cm}$, š. $\mathrm{I}, 4 \mathrm{~cm}$.

II. SE I 4, sonda I/20I 4, kv. 4, zač. inv. št. I $4 / 25$.

Namizno posodje, odlomek ustja z ostenjem rimskodobne posode, izdelane na lončarskem vretenu iz finozrnate lončarske mase (CE). Gladka površina je svetlo rdeča (IoYR 6/6). Žganje oksidacijsko. Pr. u. 8,6

I2. SE I 4, sonda I/20I 4, kv. 4, zač. inv. št. I $4 / 26$.

Namizno posodje, odlomek ustja z ostenjem rimskodobne posode, izdelane na lončarskem vretenu iz finozrnate lončarske mase (CE). Gladka površina je rdečkasto svetlo rjava (7.5YR 6.5/4). Žganje oksidacijsko. Dl. $2,5 \mathrm{~cm}$, š. $1,5 \mathrm{~cm}$.

I3. SE I 4, sonda I/20I 4, kv. I, zač. inv. št. I 4/4. Namizno posodje, odlomek ročaja rimskodobne posode, izdelane na lončarskem vretenu iz finozrnate lončarske mase (ACEF). Gladka površina je bledo rjava (IoYR 7/4). Žganje oksidacijsko. Dl. $3,8 \mathrm{~cm}$, nv. š. $1,9 \mathrm{~cm}, \mathrm{nv}$. db. $0,9 \mathrm{~cm}$.

I4. SE I 4, sonda I/20I 4, kv. I, zač. inv. št. I4/I5.

Namizno posodje, odlomek trakastega ročaja rimskodobne posode, izdelan prostoročno iz finozrnate lončarske mase (CE). Gladka površina je svetlo rdeča (7.5YR 6/8). Žganje oksidacijsko. Dl. 4,7 cm, v. $2,2 \mathrm{~cm}, \mathrm{db} .0,7 \mathrm{~cm}$.

I5. SE I 4, sonda I/20I 4, kv. 4, zač. inv. št. I $4 / 30$.

Namizno posodje, odlomek dna $\mathrm{z}$ ostenjem rimskodobne posode na prstanasti nogi, izdelane na lončarskem vretenu iz finozrnate lončarske mase (CD). Gladka površina je bledo rjava ( $\mathrm{IOYR}_{7 / 4}$ ). Žganje oksidacijsko. Pr. d. 9,5 cm, v. 3,4 cm. 
I6. SE I 4, sonda I/20I 4, kv. 4, zač. inv. št. I $4 / 19$.

Kuhinjsko posodje, odlomek ustja z ostenjem rimskodobne posode, izdelane na lončarskem vretenu iz drobnozrnate lončarske mase (ABCD). Gladka površina je temno rjava (IoYR 3/I). Žganje nepopolno oksidacijsko, $v$ zadnji fazi dimljenje. Na zunanji površini sledi saj. Dl. $2, \mathrm{I} \mathrm{cm}, \stackrel{\mathrm{s}}{\mathrm{I}} \mathrm{I}, 8 \mathrm{~cm}$.

I7. SE I 4 , sonda I/20I 4 , kv. 4, zač. inv. št. I $4 / 23$.

Kuhinjsko posodje, odlomek ustja z ostenjem rimskodobne posode, izdelane na lončarskem vretenu iz drobnozrnate lončarske mase (ABC). Gladka površina je lisasto temno rjava ( $\mathrm{IOYR}_{3} / \mathrm{I}$ in $\mathrm{IOYR}_{3} / 2$ ). Žganje nepopolno oksidacijsko, v zadnji fazi dimljenje. Dl. 2,I cm, š. 2,o cm.

I8. SE I 4 , sonda I/2OI 4 , kv. 4, zač. inv. št. I $4 / 27$.

Kuhinjsko posodje, odlomek ostenja rimskodobne posode, izdelane na lončarskem vretenu iz drobnozrnate lončarske mase (ABC). Gladka površina je lisasto temno rjava ( $\operatorname{IoYR}_{3} / \mathrm{r}$ in $\operatorname{IoYR}_{3} / 2$ ). Žganje nepopolno oksidacijsko, v zadnji fazi dimljenje. Ostenje posode je okrašeno $\mathrm{z}$ vodoravnim glavničenjem. $\mathrm{Dl}$. 4,I cm, š. $3, \mathrm{I} \mathrm{cm}$.

19. SE I 4 , sonda I/20I4, kv. 4, zač. inv. št. I $4 / 29$.

Kuhinjsko posodje, odlomek dna ostenja rimskodobne posode, izdelane na lončarskem vretenu iz drobnozrnate lončarske mase (s posameznimi grobimi vključki)(ABCEG). Groba površina je zunaj lisasto rjava in temno rjava $(7.5 \mathrm{YR}$ $5 / 4$ in $7.5 Y R \quad 4 / 2$ ) in znotraj svetlo rdeča (7.5YR 6/6). Žganje oksidacijsko. Pr. d. 7,I cm, v. $2,8 \mathrm{~cm}$.

20. SE I 4 , sonda I/20I 4 , kv. I, zač. inv. št. I $4 / 3$. Kuhinjsko posodje, odlomek roba z ostenjem rimskodobnega pokrova, izdelanega na lončarskem vretenu iz drobnozrnate lončarske mase (ACEF).
Groba površina je rjava (IoYR 5/3 zunaj, 7.5YR 5/6 znotraj). Žganje oksidacijsko. $\mathrm{Na}$ zunanji površini temnejše barve verjetno zaradi uporabe (zadimljeno). Na zunanji stran tik nad robom vodoravna kanelura. Dl. $3,3 \mathrm{~cm}$, š. $\mathrm{I}, 6 \mathrm{~cm}$.

2I. SE I 4 , sonda I/20I 4 , kv. 4, zač. inv. št. I $4 / 24$.

Kuhinjsko posodje, odlomek roba z ostenjem rimskodobnega pokrova, izdelanega na lončarskem vretenu iz drobnozrnate lončarske mase (ABC). Gladka površina je temno rjava ( IOYR $_{3} / \mathrm{I}$ ). Žganje nepopolno oksidacijsko, v zadnji 。 fazi dimljenje. Dl. $2,2 \mathrm{~cm}$, š. I, $5 \mathrm{~cm}$.

22. SE I 4 , sonda I/20I 4 , kv. I, zač. inv. št. I $4 / 8$. Transportno posodje, odlomek ostenja/ rame rimskodobne amfore (verjetno Dressel 2-6), izdelane na lončarskem vretenu iz finozrnate lončarske mase (s posameznimi drobnimi vključki) (CEF). Gladka površina je svetlo rjava (7.5YR 6/4). Žganje oksidacijsko. Dl. $4,8 \mathrm{~cm}$, š. $8, \mathrm{I} \mathrm{cm}$, db. I cm.

23. SE I 4 , sonda I/20I 4 , kv. 4, zač. inv. št. I $4 / 28$.

Namizno posodje (?), odlomek prstanastega dna rimskodobne posode, izdelane na lončarskem vretenu iz finozrnate lončarske mase (pogosti drobni vključki) (CF, večji vključki E). Gladka, poškodovana površina je rumenkasto svetlo rdeča (IOYR 6.5/6). Žganje oksidacijsko. Dl. 5, $6 \mathrm{~cm}$, š. $3,6 \mathrm{~cm}$.

24. SE I 4 , sonda I/20I 4, kv. I, zač. inv. št. I 4/7. Transportno posodje, odlomek poškodovanega ročaja $\mathrm{z}$ ostenjem rimskodobne posode, verjetno amfore, izdelane na lončarskem vretenu iz finozrnate lončarske mase (s posameznimi drobnimi in grobimi vključki) (BCEF). Gladka površina je bledo rjava (IoYR 6.5/4). Žganje oksidacijsko. Dl. $8,5 \mathrm{~cm}$, š. $8,4 \mathrm{~cm}$, ročaj - š. $4,2 \mathrm{~cm}, \mathrm{db} .2,9 \mathrm{~cm}$.

25. SE I 4 , sonda I/20I 4, kv. 3, zač. inv. št. I4/12. 
Transportno? posodje, odlomek ročaja z ostenjem rimskodobne posode, izdelane na lončarskem vretenu iz finozrnate lončarske mase (CE). Gladka površina je bledo rjava (IoYR 6.5/4). Žganje oksidacijsko. Dl. 6,I $\mathrm{cm}$, š. $6,4 \mathrm{~cm}$, ročaj - š. $6,0 \mathrm{~cm}, \mathrm{db} .2, \mathrm{I} \mathrm{cm}$.

26. SE I4, sonda I/20I 4, kv. I, zač. inv. št. I $4 / 14$.

Transportno posodje, odlomek ročaja rimskodobne posode, verjetno amfore, izdelane na lončarskem vretenu iz drobnozrnate lončarske mase (posamezni grobi vključki) (CEF). Gladka površina je bledo rjava (IOYR 8/4). Žganje oksidacijsko. Dl. $7,5 \mathrm{~cm}$, nv. š. $7,7 \mathrm{~cm}$, nv. db. 5,2 cm.

27. SE I 4 , sonda I/20I 4, kv. I, zač. inv. št. I 4/6. Transportno posodje, odlomek ročaja rimskodobne posode, verjetno amfore, izdelane na lončarskem vretenu iz drobnozrnate lončarske mase (posamezni grobimi vključki) (BCEF). Gladka površina je bledo rjava (roYR 6.5/4). Žganje oksidacijsko. Dl. 7,5 cm, š. 4,7 cm, db. 3,2 $\mathrm{cm}$.

28. SE I 4 , sonda I/20I 4, kv. I, zač. inv. št. I 4/9. Transportno posodje, odlomek poškodovanega ročaja $\mathrm{z}$ ostenjem rimskodobne posode, verjetno amfore, izdelane na lončarskem vretenu iz finozrnate lončarske mase (s posameznimi drobnimi in grobimi vključki) (CEFG). Gladka površina je bledo rjava (roYR 8/4). Žganje oksidacijsko. Dl. 4,2 cm, š. 7,0 cm, ročaj - š. $4,8 \mathrm{~cm}, \mathrm{nv}$. db. $2,7 \mathrm{~cm}$.

29. SE I 4 , sonda I/20I 4 , kv. I, zač. inv. št. I4/IO.

Transportno posodje, odlomek ročaja rimskodobne posode, verjetno amfore, izdelane na lončarskem vretenu iz finozrnate lončarske mase (s pogostimi drobnimi in grobimi vključki) (BCEF). Groba površina je svetlo rjava (IOYR 6/4). Žganje oksidacijsko. Dl. 8,I cm, š. 5,2 cm, nv. db. 3,I cm.
30. SE I 4 , sonda I/2OI 4, kv. I, zač. inv. št. I $4 /$ II.

Transportno posodje, odlomek ročaja rimskodobne posode, verjetno amfore, izdelane na lončarskem vretenu iz finozrnate lončarske mase (posamezni drobnimi vključki) (BCEF). Gladka površina je svetlo rdeča (7.5YR 6/6). Žganje oksidacijsko. Dl. 9,6 cm, nv. š. 5,6 cm, nv. db. $3,2 \mathrm{~cm}$.

3I. SE I 4, sonda I/20I 4, kv. I, zač. inv. št. I4 $/ 13$.

Transportno posodje, odlomek ročaja rimskodobne posode, verjetno amfore, izdelane na lončarskem vretenu iz drobnozrnate lončarske mase (CE). Gladka površina je bledo rjava (IoYR 7.5/4). Žganje oksidacijsko. Dl. 9, o cm, nv. š. 5,6 cm, nv. db. $2,9 \mathrm{~cm}$.

32. SE I 4 , sonda I/2OI $4, \mathrm{kv.} \mathrm{4}$, zač. inv. št. I $4 / 4 \mathrm{I}$.

Transportno posodje, odlomek ročaja rimskodobne posode, verjetno amfore, izdelane na lončarskem vretenu iz finozrnate lončarske mase (posamezni drobnimi in grobimi vključki) (CEF). Gladka površina je bledo rjava (IoYR 7.5/4). Žganje oksidacijsko. Dl. 9,5 cm, nv. š. $4,5 \mathrm{~cm}, \mathrm{nv}$. db. $2,5 \mathrm{~cm}$.

33. SE I 4 , sonda $\mathrm{I} / 20 \mathrm{I} 4, \mathrm{kv} .4$, zač. inv. št. I4/39.

Transportno posodje, odlomek dna $s$ poškodovanim zatičem $\mathrm{z}$ ostenjem rimskodobne posode, verjetno amfore, izdelane na lončarskem vretenu iz drobnozrnate lončarske mase (CEF). Gladka površina je bledo rjava (IOYR 7/4). Žganje oksidacijsko. Nv. dl. I0,3 cm, v. 3,3 $\mathrm{cm}, \mathrm{db}$. zatiča $2,6 \mathrm{~cm}$.

34. SE I 4 , sonda I/2OI 4 , kv. 4, zač. inv. št. I $4 / 3$ I.

Odlomek predilnega vretenca, izdelanega prostoročno iz drobnozrnate lončarske mase (CEG). Gladka površina je svetlo rjava (IoYR 6/4). Pr. 3,2 cm, v. 2,6 cm, pr. luknje $0,6 \mathrm{~cm}$. 
35. SE I 4 , sonda I/20I 4, kv. I, zač. inv. št. I 4/5. Odlomek predilnega vretenca, izdelanega prostoročno iz drobnozrnate lončarske mase (BCE). Gladka površina je svetlo rjava (IoYR 6/4). Pr. 3,7 cm, v. 2,5 cm, pr. luknje $0,6 \mathrm{~cm}$.

36. SE I 4 , sonda I/20I 4 , kv. I, zač. inv. št. I $4 / 20$.

Del kamnitih žrmelj, grobozrnati apnenec.

Dl. $8,0 \mathrm{~cm}$, nv. š. $4,8 \mathrm{~cm}$, nv. db. 4,0 $\mathrm{cm}$.

37. SE I 4 , sonda I $/ 2014$, kv. 3, zač. inv. št. I $4 / 2$ I.

Del kamnitih žrmelj, verjetno tekač, grobozrnata kamenina. Spodnja? stranica močno obrabljena/gladka in ravna. $\mathrm{Dl}$. Io, $6 \mathrm{~cm}$, nv. š. $7,2 \mathrm{~cm}$, nv. db. 4,3 cm.

38. SE I 4 , sonda I $/ 20 I_{4}$, kv. 4, zač. inv. št. I $4 / 22$.

Del kamnitih žrmelj, tekač, grobozrnati peščenjak. Klinaste oblike, slabo ohranjen robnik. Dl. I 4,5 cm, š. $8,3 \mathrm{~cm}$, nv. db. 9,2 $\mathrm{cm}$.

39. SE I 4, sonda I/20I 4, kv. 4, zač. inv. št. $14 / 32$.

Kamnita kocka, drobnozrnati peščenjak svetlo rumenkasto rjave barve (2.5Y 6/4). Dl. stranic med 2, 4 in 2,7, v. med 2,0 in 2,2 $\mathrm{cm}$.

40. SE I 4 , sonda I/20I 4 , kv. 4, zač. inv. št. I4/17.

Kamnit valjast izvrtek, ovalnega preseka, drobnozrnati peščenjak svetlo rjave barve (7.5YR 6/4), morda sekundarno ožgan. Dl. I, I cm, š. $0,9 \mathrm{~cm}$, V. I, $7 \mathrm{~cm}$.

4I. SE I 4, sonda I/20I 4, kv. 4, zač. inv. št. $14 / 18$.

Kos svinca, nepravilne oblike. Dl. 2,5 cm, š. $2,3 \mathrm{~cm}, \mathrm{db} .0,2 \mathrm{~cm}$, teža $16 \mathrm{~g}$.

42. SE I6, sonda I/20I 4, kv. I, zač. inv. št. I6/2. Transportno posodje, odlomek ostenja/ rame rimskodobne amfore (verjetno Dressel 2-6), izdelane na lončarskem vretenu iz finozrnate lončarske mase (s posameznimi grobimi vključki) (CEF). Gladka, poškodovana površina je bledo rjava (IoYR 7.5/4). Žganje oksidacijsko. $\mathrm{Na}$ zgornjem delu ramena verjetno nastavek za ročaj. Dl. 9,4 cm, š. 5,4 cm, nv. š (rame) 24 $\mathrm{cm}$.

43. SE I6, sonda I/20I 4 , kv. I, zač. inv. št. I6/I. Odlomek rimskodobne tegule, iz finozrnate lončarske mase (s pogostimi drobnimi in grobimi vključki) (CEF). Gladka površina je bledo rjava (IoYR 7.5/4). Žganje oksidacijsko. Dl. II,9 cm, š. $7,4 \mathrm{~cm}$, v. $6,5 \mathrm{~cm} \mathrm{db} .3,2 \mathrm{~cm}$.

44. SE I3, sonda I/20I4, kv. 4, zač. inv. št. I3/4. Namizno posodje, odlomek dna rimskodobne posode na prstanasti nogi, izdelane na lončarskem vretenu iz finozrnate lončarske mase (posamezni drobni vključki) (CEF). Gladka površina je na zunanji strani bledo rumena $(2.5 \mathrm{Y} 7 / 3)$, na notranji strani pa bledo rjava (IoYR 7/4). Žganje oksidacijsko. Dl. 3,7 cm, š. I,9 $\mathrm{cm}$.

45. SE I3, sonda I/20I 4 , kv. 4, zač. inv. št. I3/2. Kuhinjsko posodje, odlomek ostenja rimskodobne posode, izdelane na lončarskem vretenu iz drobnozrnate lončarske mase (BEG). Gladka površina je na zunanji strani lisasta sivo temno rjava (IOYR 4/I in IO YR 4/2), na notranji pa rumena (2.5Y 6/4). Ž ganje redukcijsko. $\mathrm{Na}$ odlomku je okras poševnih pasov kanelur, motiv ribje kosti. Dl. $3,9 \mathrm{~cm}, \mathrm{~s}^{3}, 3,8 \mathrm{~cm}$.

46. SE I3, sonda I/20I 4, kv. 3, zač. inv. št. I3/5. Kuhinjsko posodje, odlomek dna z ostenjem rimskodobne posode, izdelane na lončarskem vretenu iz drobnozrnate lončarske mase (BCD). Gladka površina je zunaj lisasta svetlo rdeča, svetlo rjava in sivo črna (7.5YR 6/6, 10YR 3/2 ter 2.5Y 6/3), znotraj pa svetlo rdeča (7.5YR 6/6). Žganje redukcijsko, v končni fazi oksidacijsko. $\mathrm{Na}$ zunanji površini sledi saj, dno sekundarno žgano?. Dl. $3,3 \mathrm{~cm}$, š. $1,9 \mathrm{~cm}$.

47. SE I3, sonda I/20I 4, kv. 4, zač. inv. št. I3/3. Kuhinjsko posodje, odlomek dna z ostenjem rimskodobne posode, izdelane na lončarskem vretenu iz drobnozrnate 
lončarske mase (BCDF). Gladka površina je temno rjava (IoYR 3/I). Žganje redukcijsko. Dl. $2, \mathrm{I} \mathrm{cm}$, š. I, $4 \mathrm{~cm}$.

48. SE I3, sonda I/2OI 4, kv. 4, zač. inv. št. I3/I. Kuhinjsko posodje, odlomek roba z ostenjem rimskodobnega pokrova, izdelane na lončarskem vretenu iz drobnozrnate lončarske mase (ABCDE). Gladka površina je rjava ( 5 YR s/8). Žganje oksidacijsko. Na robu sledi zadimljenosti. Dl. $4,7 \mathrm{~cm}, \mathrm{~s} .2,0 \mathrm{~cm}$.

49. SE $\mathrm{I}_{3}$, sonda I/20I $4, \mathrm{kv} .3$, zač. inv. št. I3/6. Ovalen ploščat kamnit predmet, morda utež (?). Finozrnati peščenjak, svetlo rumenkasto rjave barve (2.5Y 6/3). Dl. 7,I $\mathrm{cm}$, š. $5,1 \mathrm{~cm}, \mathrm{db} .2,0 \mathrm{~cm}$.

50. $\mathrm{SE}_{3}$, sonda I/20I 4, kv. 3, zač. inv. št. 3/2. Kuhinjsko posodje, odlomek ustja z ostenjem rimskodobne posode, verjetno lonca, izdelanega na lončarskem vretenu iz drobnozrnate lončarske mase (ABCD). Groba površina je temno rjava ( IoYR $\left._{3} / \mathrm{I}\right)$.

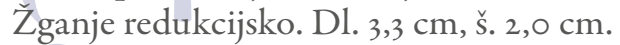

5I. SE 3 , sonda I/2OI $4, \mathrm{kv} .3$, zač. inv. št. $3 / 3$. Transportno posodje, odlomek poškodovanega ročaja rimskodobne posode, verjetno amfore, izdelane na lončarskem vretenu iz finozrnate lončarske mase (s posameznimi drobnimi in grobimi vključki) (CEF). Gladka površina je bledo rjava (roYR 6/4).Žganje oksidacijsko. Dl. $5,2 \mathrm{~cm}$, nv. š. $6,4 \mathrm{~cm}, \mathrm{nv}$. db. $3,4 \mathrm{~cm}$.

52. $\mathrm{SE}_{3}$, sonda $\mathrm{I} / 20 \mathrm{I}_{4}, \mathrm{kv} .3$, zač. inv. št. 3/4. Transportno posodje, odlomek poškodovanega ročaja rimskodobne posode, verjetno amfore, izdelane na lončarskem vretenu iz finozrnate lončarske mase (s posameznimi drobnimi in grobimi vključki) (CEF). Gladka površina je svetlo rjava (7.5YR 6/4). Žganje oksidacijsko. Dl. $9,9 \mathrm{~cm}, \mathrm{nv}$. s. $4,6 \mathrm{~cm}, \mathrm{nv}$. db. $2,8 \mathrm{~cm}$.

53. $\mathrm{SE}_{3}$, sonda I/20I $4, \mathrm{kv}$. 3, zač. inv. št. 3/I. Kamnit odlomek brusa, finozrnati peščenjak. Ovalnega preseka, na eni strani stanjšanega. Dl. 8,o cm, nv. š. 4, O cm, nv. db. $2,6 \mathrm{~cm}$.
54. SE $4 / 2$, sonda I/20I 4, kv. I, zač. inv. št. $4 / 2 / 1$.

Transportno posodje, odlomek zatiča rimskodobne amfore, izdelane na lončarskem vretenu iz finozrnate lončarske mase (posamezni grobi vključki) (CEF). Gladka površina je bledo rjava (IOYR 6/4). Žganje oksidacijsko. Pr. d. 3,4 cm, nv. dl. $9,3 \mathrm{~cm}$, v. $5,6 \mathrm{~cm}, \mathrm{db}$. zatiča $4,0 \mathrm{~cm}$.

55. KS I, zač. inv. št. KS/I/I.

Transportno? posodje, odlomek ostenja/ rame rimskodobne posode, izdelane na lončarskem vretenu iz finozrnate lončarske mase (s pogostimi drobnimi in grobimi vključki) (BCEF). Gladka površina je bledo rjava (IoYR 7/4). Žganje oksidacijsko. Dl. 9,4 cm, š. $5,5 \mathrm{~cm}$.

56. KS 2, zač. inv. št. $\mathrm{KS} / 2 / \mathrm{I}$. Odlomek rimskodobnega stekla turkizne barve. Dl. 2,6 cm, š. I, $8 \mathrm{~cm}, \mathrm{db} .0,2 \mathrm{~cm}$.

57. Čiščenje profila PI, zač. inv. št. SVP/I. Kuhinjsko posodje, odlomek ustja z ostenjem rimskodobne posode, izdelane na lončarskem vretenu iz drobnozrnate lončarske mase (s pogostimi grobimi vključki) (BCF). Gladka površina je temno rjava (7.5YR 6/6). Žganje oksidacijsko. Dl. $3,2 \mathrm{~cm}, \breve{s} .1,7 \mathrm{~cm}$. 

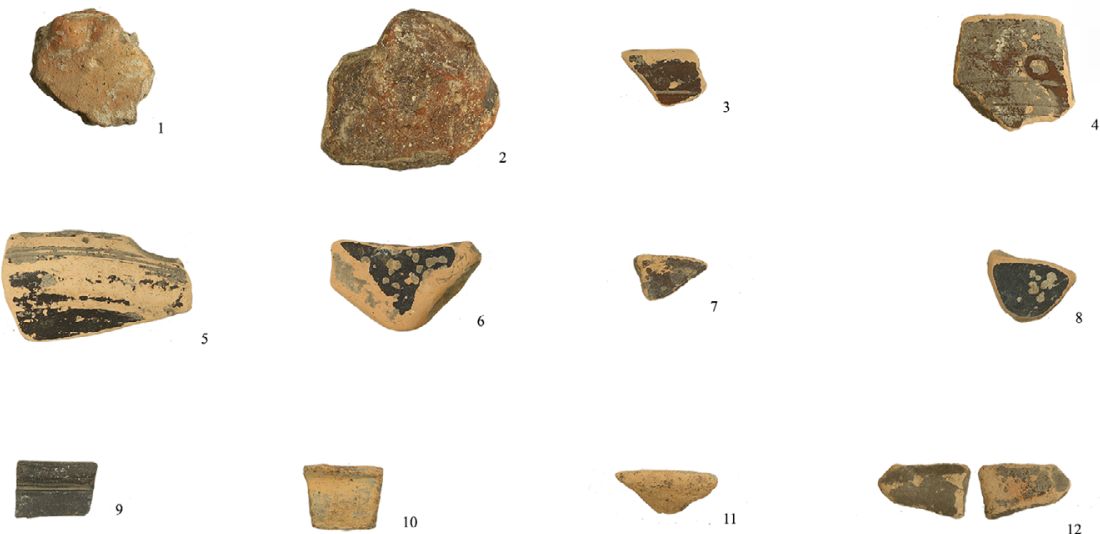

$\infty$
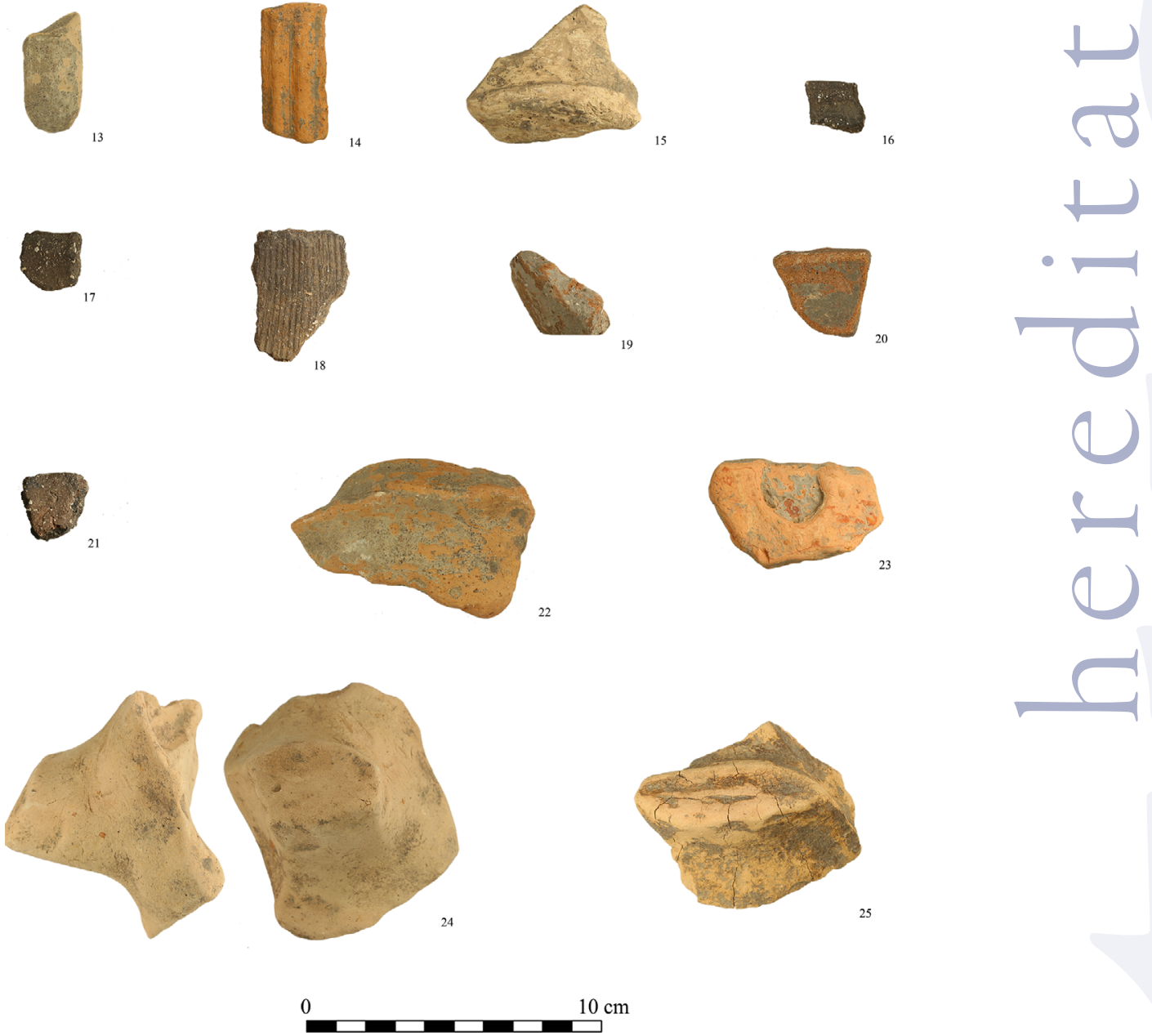

Slika 8. Kaštelir na Kortami, izbor, v fotografiji predstavljenega arheološkega gradiva (fotografije predmetov so označene s kataložnimi številkami) (foto: A. Ogorelec, arhiv IAD UP FHŠ). 

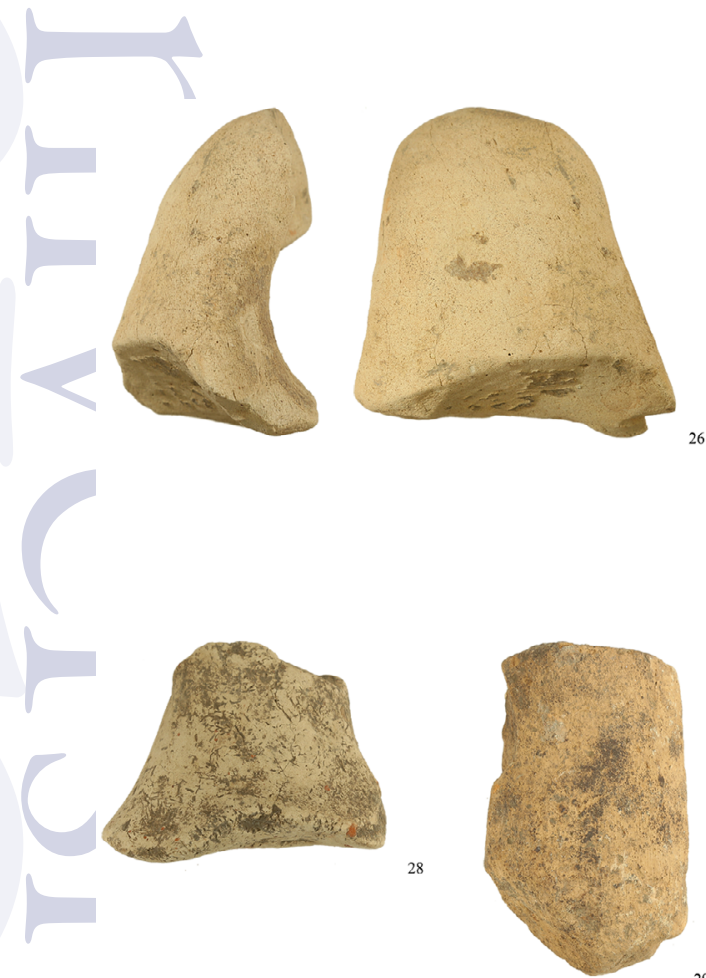

29
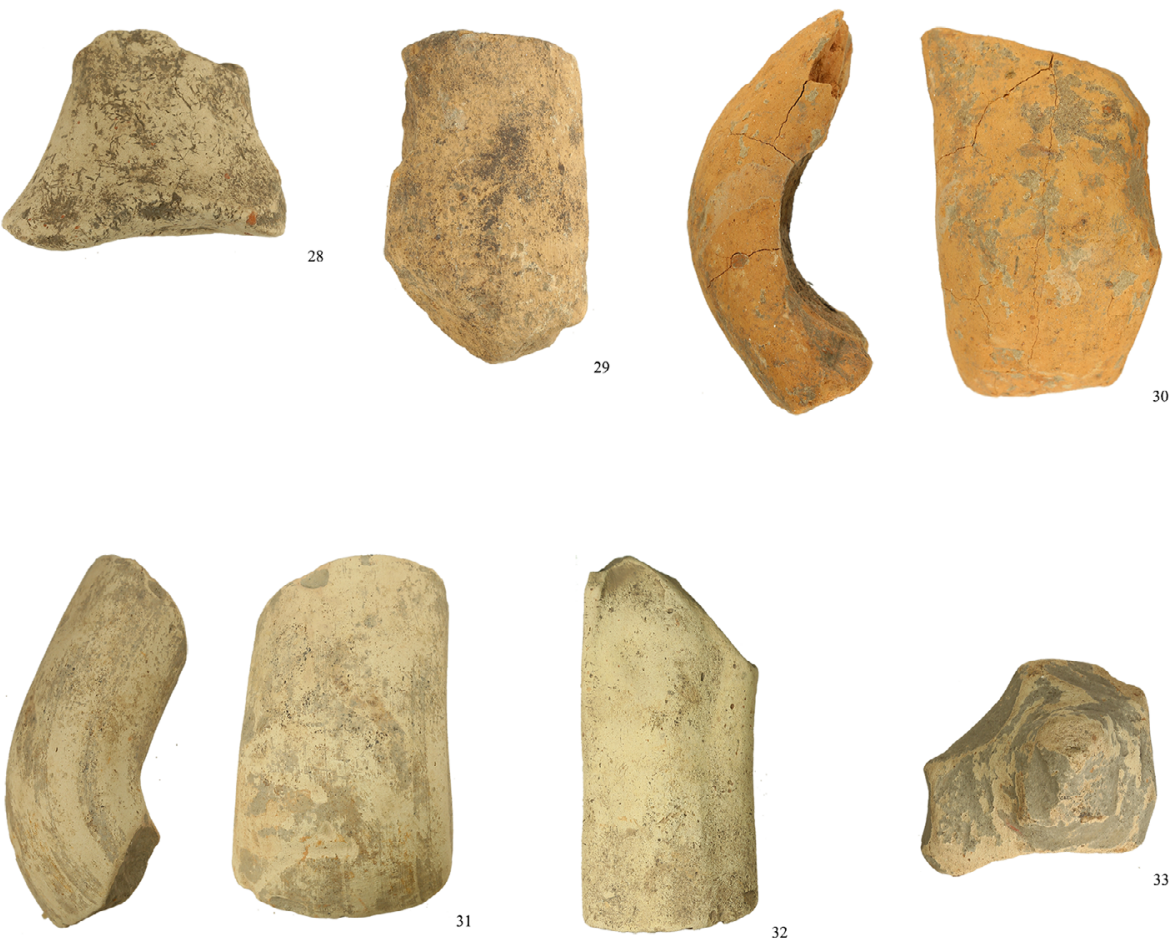

32

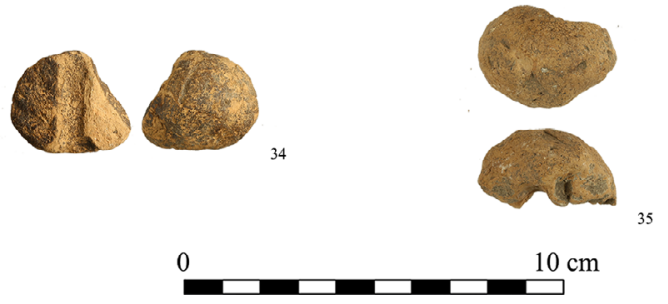

$\infty$

Slika 9. Kaštelir na Kortami, izbor, v fotografiji predstavljenega arheološkega gradiva (fotografije predmetov so označene s kataložnimi številkami) (foto: A. Ogorelec, arhiv IAD UP FHŠ). 

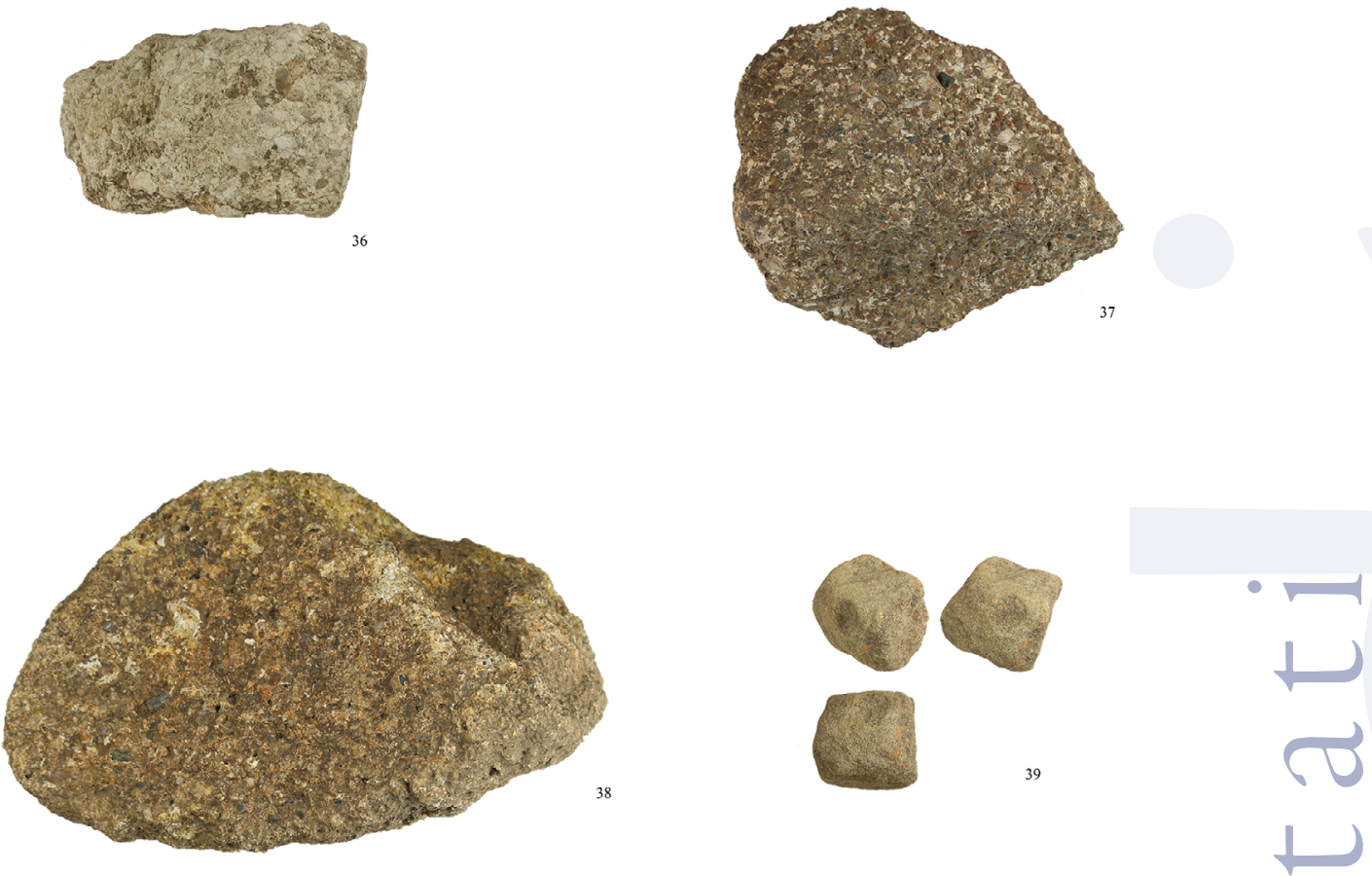

$\infty$

38
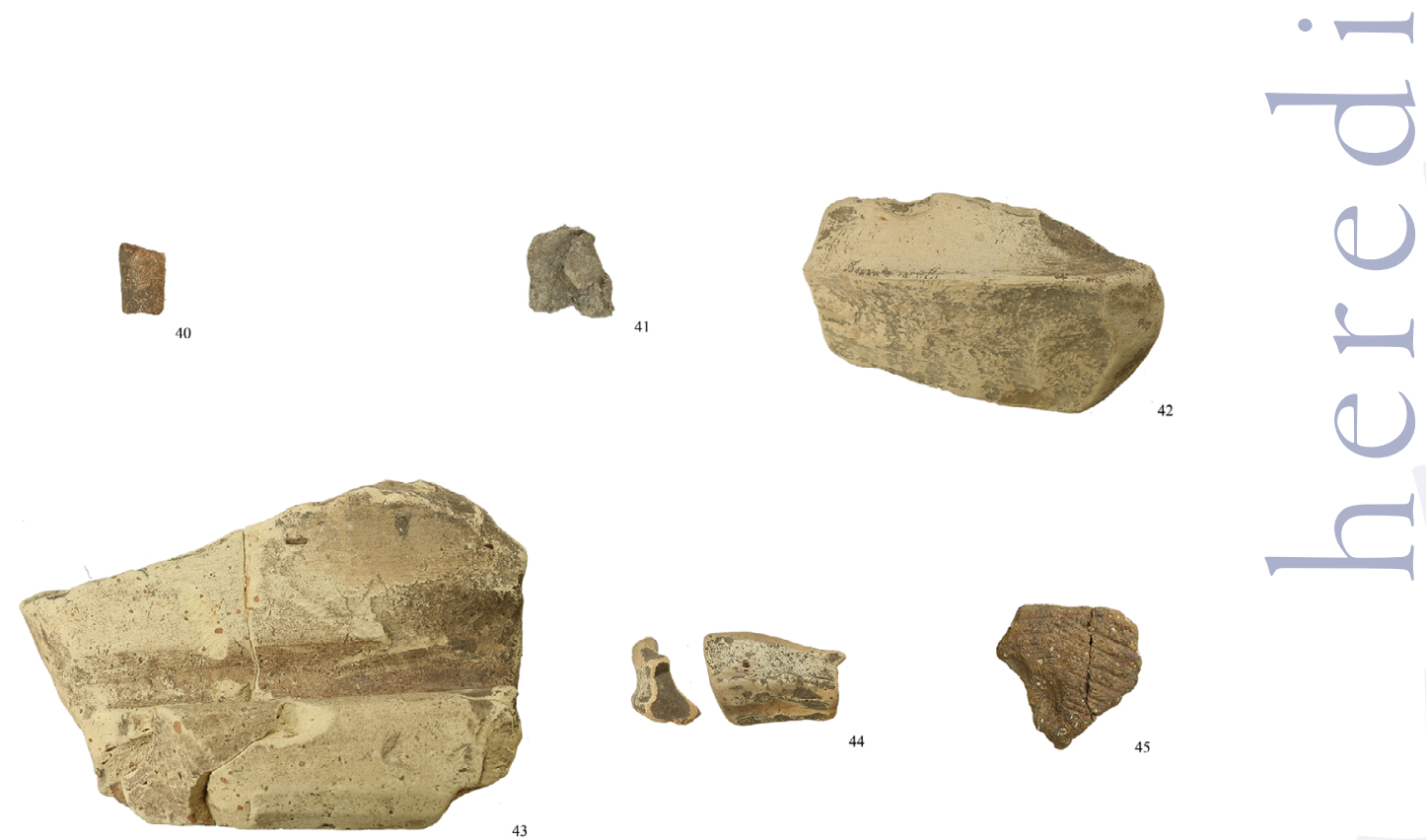

41
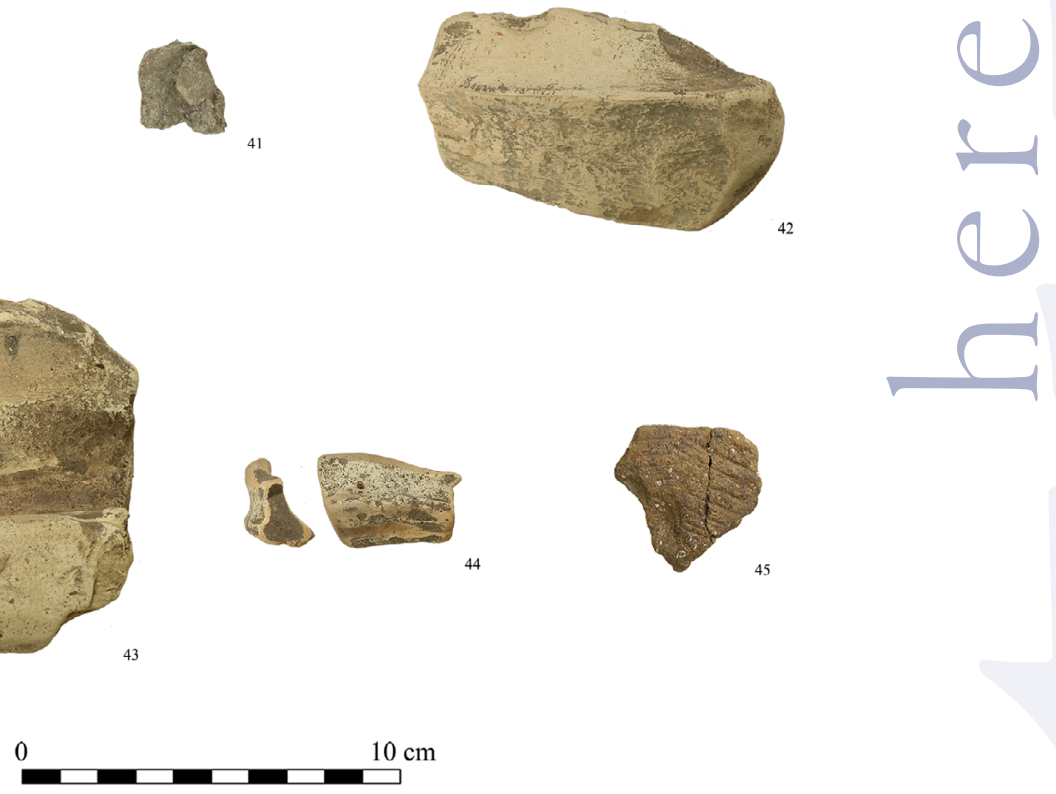

Slika ı. Kaštelir na Kortami, izbor, v fotografiji predstavljenega arheološkega gradiva (fotografije predmetov so označene s kataložnimi številkami) (foto: A. Ogorelec, arhiv IAD UP FHŠ). 


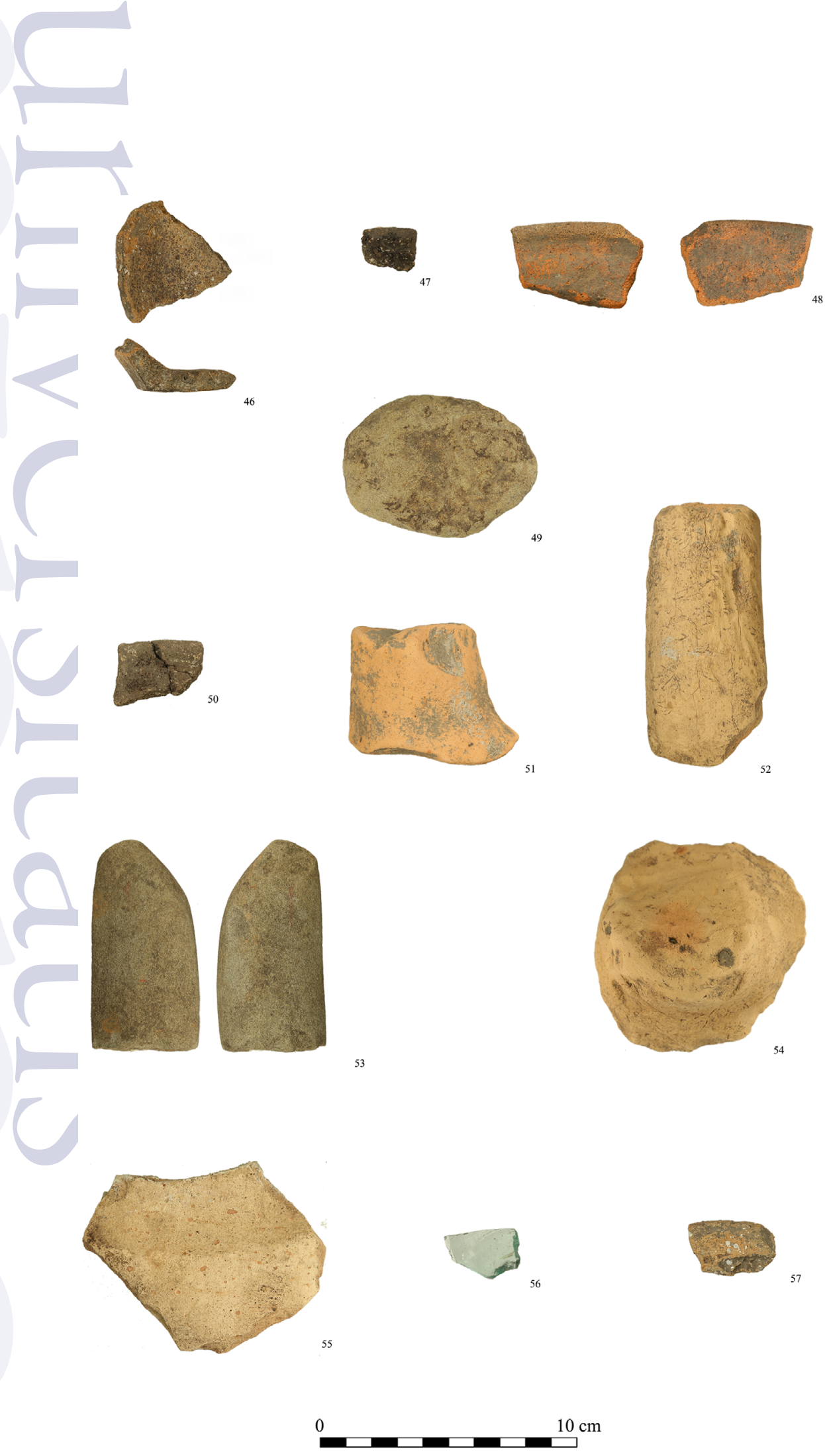

Slika II. Kaštelir na Kortami, izbor, v fotografiji predstavljenega arheološkega gradiva (fotografije predmetov so označene s kataložnimi številkami) (foto: A. Ogorelec, arhiv IAD UP FHŠ). 

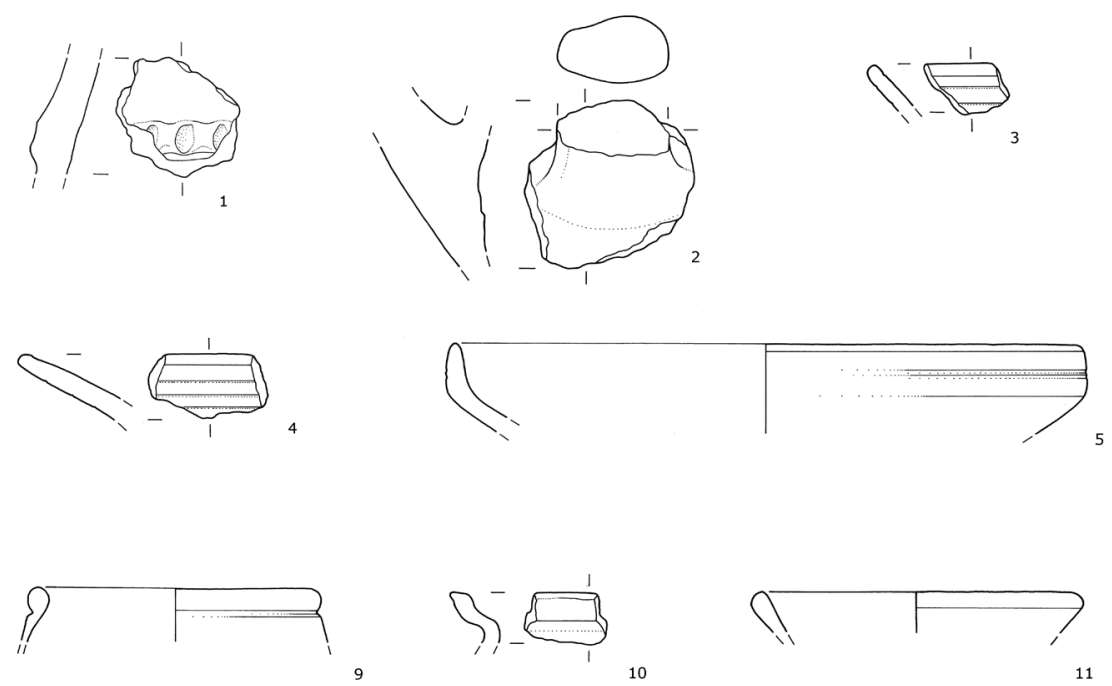

11

$\bullet$
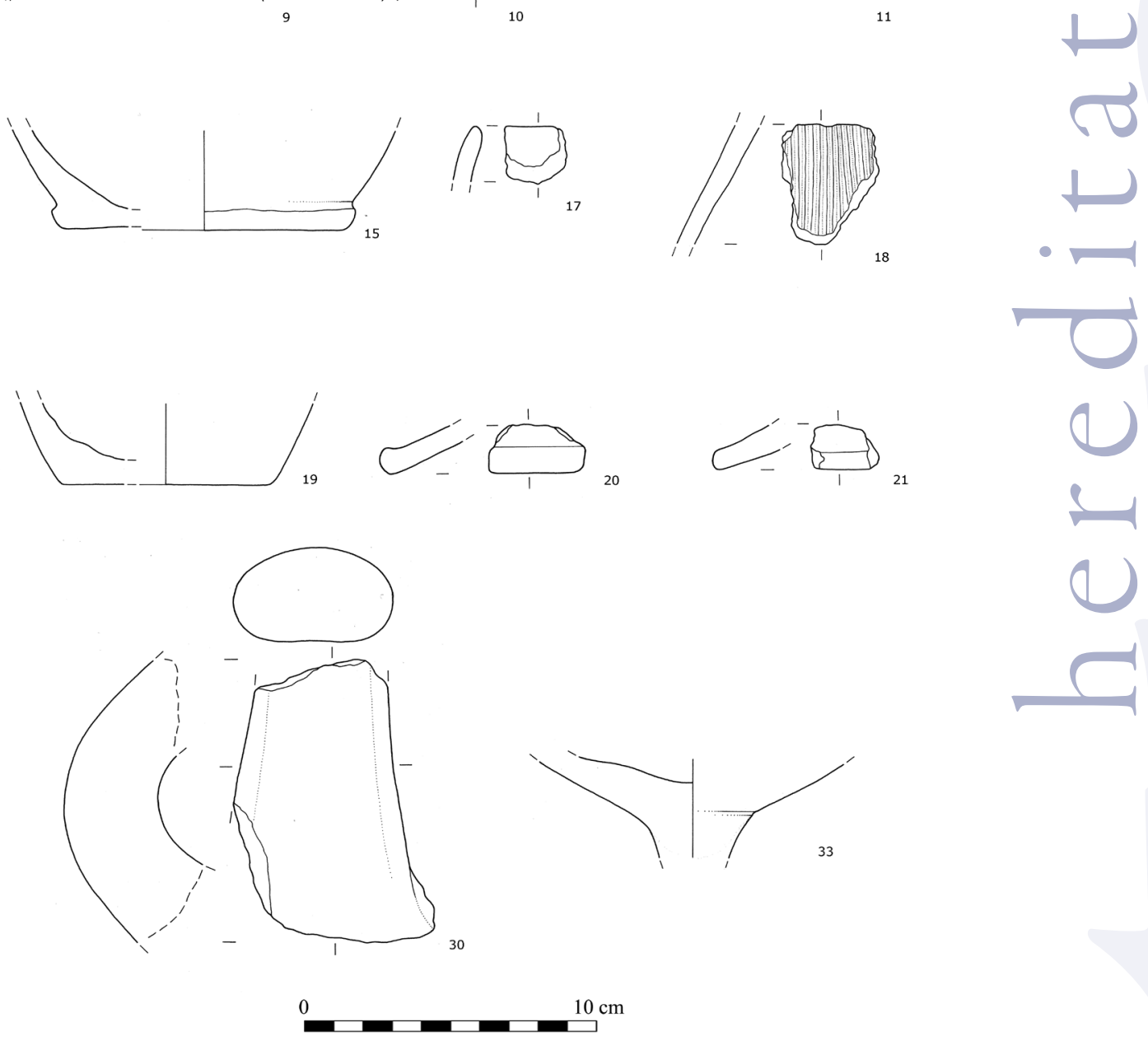

Slika I2. Kaštelir na Kortami, izbor, v risbi predstavljenega arheološkega gradiva (risbe so označene s kataložnimi številkami) (risba: Janja Tratnik Šumi). 

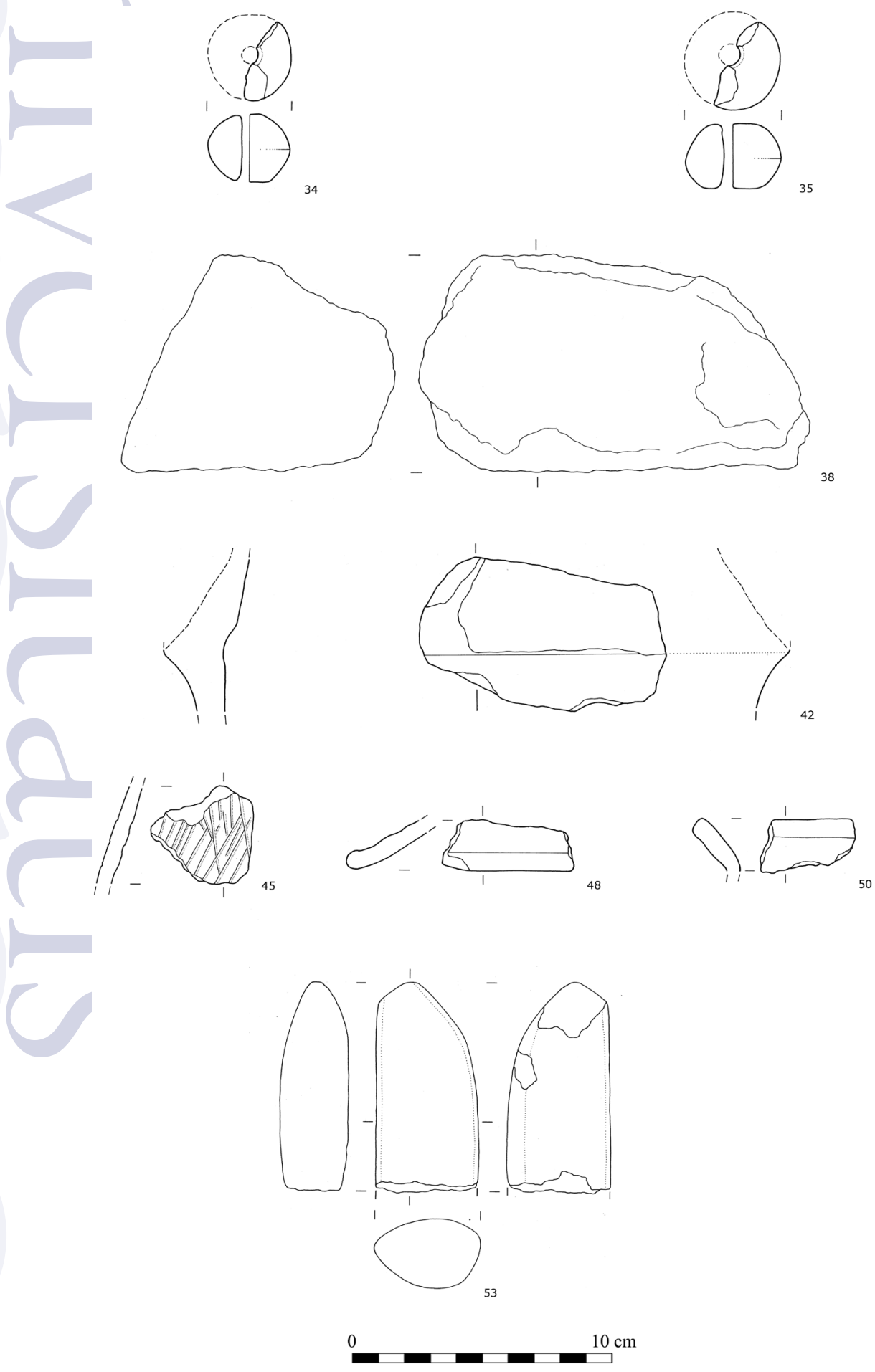

Slika i3. Kaštelir na Kortami, izbor, v risbi predstavljenega arheološkega gradiva (risbe so označene s kataložnimi številkami) (risba: Janja Tratnik Šumi). 

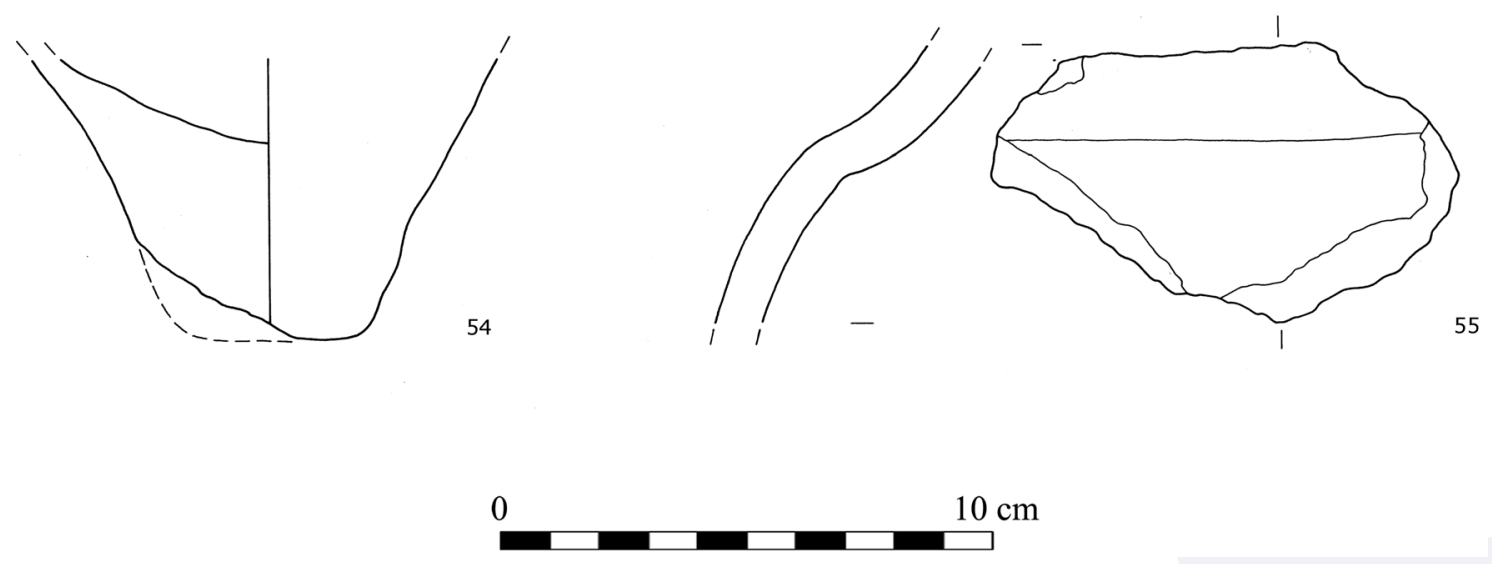

Slika i4. Kaštelir na Kortami, izbor, v risbi predstavljenega arheološkega gradiva (risbe so označene s kataložnimi številkami) (risba: Janja Tratnik Šumi).

\begin{tabular}{|c|c|c|c|c|c|c|c|c|c|}
\hline Podatki & & & & Gradivo & & & \multirow[b]{2}{*}{ školjke } & & 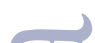 \\
\hline SE & keramika & kamni & gr. mat. & žel. predmeti & steklo & kosti & & & \\
\hline $\mathrm{SE}_{3}$ & 109 & I & 26 & & & 7 & 4 & & \\
\hline $\mathrm{SE}_{5}$ & I & & & & & & & & \\
\hline SE 8 & 8 & & & & & & I & - & \\
\hline $\mathrm{SE}_{9}$ & 23 & & & & & & 3 & & \\
\hline SE IO & 5 & & & & & 2 & $\mathrm{I} 2$ & & \\
\hline $\mathrm{SE}_{13}$ & 203 & I & I & & & 10 & 26 & & \\
\hline SE 16 & 35 & & I & & & 5 & 5 & & \\
\hline $\mathrm{SE}_{4 / 2}$ & 6 & & & & & I & 3 & & \\
\hline $\mathrm{SE}_{\mathrm{I} 4}$ & 1739 & 6 & 7 & & & 231 & 634 & & \\
\hline
\end{tabular}

Slika I5. Kaštelir na Kortami, tabelarični prikaz numerične zastopanost najdb glede na vrsto gradiva, po posameznih kontekstih (SE).

\section{Analiza in interpretacija arheološkega drobnega gradiva}

Arheološko drobno gradivo, odkrito v sondi I, sodi večinoma $\mathrm{v}$ rimsko obdobje, nekaj odlomkov je prazgodovinskih, odkrit pa je bil tudi novodoben železni predmet. Glede na zastopanost najdb po posameznih arheoloških kontekstih, ugotavljamo, da je bilo največ najdb odkritih $\mathrm{v}$ plasti SE I4, med največ odlomkov keramičnega gradiva $(\mathrm{N}=1739)$, posamezni obdelani kamni $(\mathrm{N}=6)$, odlomki gradbenega materiala $(\mathrm{N}=7)$, številni deli živalskih kosti $(\mathrm{N}=23 \mathrm{I})$ ter obilica školjk (N=634) (sl. I5, 16). Razmeroma številč̌no je bilo arheološko gradivo še v plasteh SE 13 in $\mathrm{SE}_{3}$, sicer pa so bile najdbe $\mathrm{v}$ evidentiranih arheoloških plasteh in ostalinah razmeroma maloštevilne (sl. I5, 16).

Prazgodovinske najdbe so bile v sondi I razmeroma redke. Keramika podobnih oblik, okrasa in tehnološke izdelave, kot sta odlomka posodja iz plasti SE 14: GI, G22, je bila najdena tudi v preteklih arheoloških raziskavah na Kašte- 


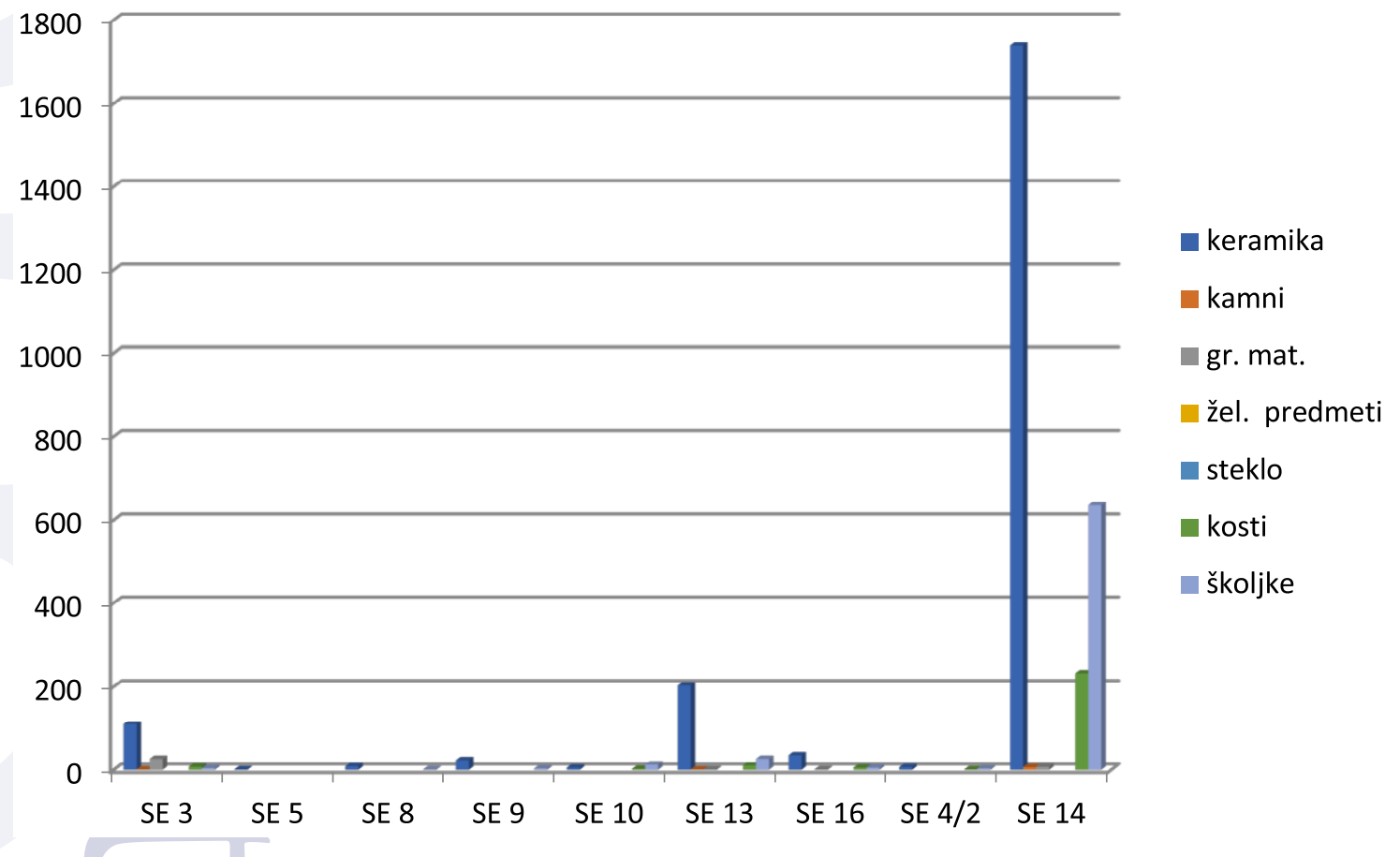

Slika ı6. Kaštelir na Kortami, grafični prikaz zastopanosti arheoloških najdb, po posameznih kontekstih (SE).

lirju ${ }^{16}$ kakor tudi npr. na Serminu ${ }^{17}$ in jo lahko pripišemo bronastodobni poselitvi obravnavanega območja.

Med rimskodobnimi najdbami so bili $\mathrm{v}$ sondi I odkriti razmeroma številni odlomki izdelkov iz keramike, med njimi odlomki finega namiznega posodja, namiznega posodja, kuhinjskega posodja in transportnega posodja, odlomki kamnitih predmetov, med njimi npr. odlomki žrmelj in brusa, ter fragmenti svinca.

\section{Fino namizno posodje}

Keramika s črnim premazom je v sondi $\mathrm{I} / 20 \mathrm{I} 4$ zastopana s 7 odlomki (G3, G4, G5, G6, G7, G8, G9), odlomki ustij in ostenji, npr. v plasti SE i4. Tovrstna keramika je razprostranjena po celotni obali (npr. Sermin, Fornače, Piran, Pulj, Pomljan, Simonov zaliv idr.) ter je v uporabi od 4. (zahodno Sredozemlje in Italija) do začetka

I6 Sakara Sučevič, Prazgodovinska keramika med Miljskim zalivom in porečjem Mirne, npr. G558, G582, G583, G600, G601, idr.

17 Sakara Sučevič, Prazgodovinska keramika med Miljskim zalivom in porečjem Mirne, npr. Gi87.
I. stoletja pr. n. št. najstarejši primerki v Istri so poznani iz Nezakcija (sr. 3, zač 2. stoletja pr. n. št.). Tovrstno keramiko so izdelovale delavnice v Etruriji, Padaski nižini ter na severozahodni jadranski obali, medtem ko so primerki slabše kvalitete izdelovale delavnice v Riminiju, morda celo v Akvileji in njeni okolici (severnojadranske delavnice).

V prvi polovici I. stol. pr. n. št. se v severni Italiji razvije posebna proizvodnja t. im. srednjepadanska keramika s črnim premazom, ki je bila razširjena po vsej Padski nižini in je dosegla tudi Štalensko goro (tam je poimenovana porozni fabrikat) ${ }^{18}$. Skleda (primerek Gs) ima podobne analogije tudi na Fornačah ${ }^{19}$ in $\mathrm{Okri}^{20}$.

\footnotetext{
I8 Marko Stokin, "Naselbinski ostanki iz ı. st. pr. n. št. v Fornačah pri Piranu," Arheološki vestnik 43 (1992): 84; Jana Horvat in Alma Bavdek, Okra, Vrata med Sredozemljem in Srednjo Evropo, Opera Instituti Archaeologici Sloveniae i7 (Ljubljana: ZRC SAZU, 2009), 57.

I9 Stokin, "Naselbinski ostanki iz i. st. pr. n. št.v Fornačah pri Piranu," t. $2 / \mathrm{I}, 3$.

20 Jana Horvat in Alma Bavdek, Okra, Vrata med Sredozemljem in Srednjo Evropo, Opera Instituti Archaeologici Sloveniae i7 ( Ljubljana: ZRCSAZU, 2009), t. 40/1, masa ČP3.
} 
Keramika s črnim premazom je bila najdena tudi na Serminu ${ }^{21}$. Izdelke poroznega fabrikata/srednjepadanske keramike so izdelovali v obdobju od konca 2. stoletja pr. n. št. do začetka I. stoletja n.št. ${ }^{22}$.

\section{Namizno posodje}

Namizno posodje (primerki Gıo, GII, GI2, GI3, Gi4, Gi5, G44) iz različnih stratigrafskih enot (SE I 4, SEI3) je verjetno severno jadranske proizvodnje in je pogosto na najdiščih na Slovenski obali, npr. Sermin ${ }^{23}$ in slovenskega zaledja, predvsem ob prometnicah, npr. na Okri ${ }^{24}$.

\section{Kuhinjsko posodje}

Kuhinjska keramika (primerki Gi7, Gi8, Gi9, $\mathrm{G}_{20}$, G21, G45, G46, G47, G48, G50, G57, G23, $\mathrm{G}_{25}, \mathrm{G}_{55}$ ) je bila odkrita na primer v plasteh $S E$ ${ }_{14}$, SE $\mathrm{I}_{3}$ in $\mathrm{SE}_{3}$ in je časovno težje opredeljiva, saj je bila po večini izdelek lokalnih delavnic. Podoben okras glavničenja na kuhinjskih loncih kot na primerku Gi8 se pojavlja tudi na Fornačah ${ }^{25}$, prav tako je iz istega najdišča podoben lonec kot naš primerek $\mathrm{G}_{5} \mathrm{O}^{26}$.

\section{Transportno posodje}

Velik del keramičnih odlomkov pripada transportnemu posodju, ki je bilo odkrito na primer v plasteh SE 14, SE 16 in $\mathrm{SE}_{3}$ (primerki G22, G23, $\mathrm{G}_{24}, \mathrm{G}_{26} 6, \mathrm{G}_{27}, \mathrm{G}_{28}, \mathrm{G}_{29}, \mathrm{G}_{31}, \mathrm{G}_{32}, \mathrm{G}_{33}, \mathrm{G}_{42}$, G51, G52, G54).

Amfore tipa Lamboglia 2 in kasneje Dressel 6A sta značilni obliki transportnega posodja $v$ zgodni antiki. Lamboglia 2 se je pojavljala $\mathrm{v}$ času od konca 2. stoletja do sredina $\mathrm{I}$. stoletja pr. n. št. na jadranski obali in je bila namen-

\footnotetext{
2 I Ana Plestenjak, ur., Sermin, Arheološke raziskave v letu 2010, (Ljubljana: Arhej d.o.o., 2012), 93, npr. G92.

22 Plestenjak, Sermin, Arbeološke raziskave v letu 20I0,93.

23 Plestenjak, Sermin, Arheoloske raziskave v letu 2010, 94

24 Jana Horvat in Alma Bavdek, Okra, Vrata med Sredozemljem in Srednjo Evropo, Opera Instituti Archaeologici Sloveniae 17 ( Ljubljana: ZRCSAZU, 2009), 74 .

25 Stokin, "Naselbinski ostanki iz i. st. pr. n. št. v Fornačah pri Piranu," t. $4 / 3$.

26 Stokin, "Naselbinski ostanki iz i. st. pr. n. št. v Fornačah pri Piranu," t. $4 / 2$.
}

jena transportu vina. Istočasno (konec 2. stoletja pr. n. št. do srednjeavgustejskega obdobja) se na zahodnojadranski obali razvije ovaloidna oblika Bransidi, namenjena transportu olja. Kasneje v zadnji tretjini I. stoletja pr. n. št. v delavnicah severozahodnega in vzhodnega Jadrana začnejo izdelovati robustnješo obliko amfor, ki nadomestijo obliko Lambogia 2, Dressel 6A. Obe obliki amfor sta hruškaste oblike z okroglimi ročaji in visokim zatičem, medtem ko je oblika Brindisi ovalne oblike s kratkim zatičem ${ }^{27}$.

$\mathrm{Na}$ podlagi analogij smo amforam tega tipa pripisali tudi odlomke ostenij $\mathrm{G}_{22}$ in $\mathrm{G}_{42}$ ter večino ročajev transprotnega posodja ovalnega preseka. Dno amfore $\mathrm{z}$ delno ohranjenim zatičem $\mathrm{G}_{33}$ in ročaj $\mathrm{G}_{30}$ bi lahko bili del amfore Brindisi. Zatič $\mathrm{G}_{33}$ je sorazmeroma kratek in morda pripada amfori tipa Dressel 2-6. Med transportno posodje smemo prišteti tudi odlomke, ki po masi in obliki niso značilni za amfore, verjetno pa so odlomki večjih shrambenih posod (primerki G23, G25, G55).

\section{Ostalo}

V sondi I so bili najdeni tudi trije odlomki ročnih mlinov - žrmlje (primerki G36, G37, G38), iz različnih kamenin, vendar le en $\left(\mathrm{G}_{3} 8\right)$ opredeljen kot zgornji kamen - tekač. Odkrita sta bila tudi odlomek kamnitega brusa (G53) v SE 3 ter odlomek kamnite kocke (G39) v SE I4.

Fragmenti svinca $\left(\mathrm{G}_{4} \mathrm{I}\right)$ so bili najdeni tudi na Serminu (k. št. 88, ı80, 500), kjer so bili interpretirani kot uteži za ribiške mreže ${ }^{28}$. Tudi keramični predmeti, podobni sicer predilnim vretencem, bi se lahko uporabljali pri ribolovu kot uteži, morda plovci.

Podobo so opredeljeni predmeti najdeni na Fornačah pri Piranu ${ }^{29}$. Kot pripomočke za ribolov bi lahko umestili tudi kamnit ovalen predmet, morda kamnito utež (G49).

\footnotetext{
27 Verena Vidrih Perko, Amfore v Sloveniji, Annales, Ser. hist. sociol. io, št. 2 (22), (2000), 42 I-456; Silvia Cipriano in Francesca Ferrarini, Le amfore romane di Opitergium, Cornuda (Oderzo: Lions club di Oderzo, 200I), 53 .

28 Plestenjak, Sermin, 34.

29 Stokin, "Naselbinski ostanki iz i. st. pr. n. št. v Fornačah pri Piranu," t. $5: 6-8$.
} 
Interpretacija arheoloških plasti in arheoloških ostalin v sondi I

Stratifikacija plasti in struktur se je na raziskanem območju najdišča izkazala za enostavno. Vse evidentirane ostaline so bolj ali manj vezana na procese in dejavnosti, ki so se odvijale v rimskem obdobju. Najstarejšo evidentirano plast na tem delu najdišča predstavlja SE I4 ( $f a z a I)$, kulturna plast, ki je ležala neposredno na geološki osnovi SE is. Odkrita je bila na celotni raziskani površini sonde, predvidevamo pa tudi, da se nahaja še izven izkopnega polja. Nanjo odložena ruševinska plast SE 16, ki je bila dokumentirana v zahodnem delu sonde, in je po strukturi močno podobna SE I2, zaradi česar sklepamo, da sta obe evidentirani plasti posledica iste aktivnosti in sta sočasni ( faza 2). Konstrukcija kamnite strukture I se je začela po odložitvi SE i6 in SE I2. Najprej je bil izgrajen notranji del, sestavljen iz manjših kamnov in lomljencev (SE 4), kateri je bil nato zamejen $\mathrm{z}$ vencem iz večjih kamnitih plošč SE 2. Gradnja notranjih elementov kamnite strukture pripada $f a z i$, gradnja obodnega venca pa fazi 4 . Sledilo je formiranje plasti SE I3, ki se je odložila le v skrajnem severnem vogalu sonde ob kamniti strukturi in nato nanjo tudi plast SE 9. Obe vključujeta rimskodobne najdbe, v $S E$ i3 pa so bili odkriti tudi posamezni odlomki prazgodovinske lončenine. SE 9 je prekrila plast $S_{3}$, ki se je podobno kot SE 9 in SE 13 odložila le ob obstoječi kamniti strukturi I. V njej sta bila poleg razmeroma številnega rimskodobnega keramičnega gradiva odkrita tudi dva odlomka, ki bi ju morda lahko pripisali srednjeveškemu obdobju. $S$ pravi, da je nastala bistveno kasneje od predhodnih SE 9 in SE I3. Vse skupaj je prekrila travna ruša SE I.

Čiščenje kamnitih struktur $I$ in 2 na parc. št. 1504 k.o. Dvori nad Izolo

Ob testnih sondiranjih se je izvajalo tudi čiščenje in dokumentiranje kamnitih struktur $\mathrm{I}$ in 2 na parc. št. 1504 k.o. Dvori nad Izolo (sl. 4). Čiščenje kamnitih struktur je potekalo na način, da se je odstranilo podrastje in suho listje, arhitekturni ostanki in zemljeni depoziti pa so se ohranjali na mestu odkritja. Strukturi sta se očistili do te mere, da je bilo možno geodetsko merjenje in fotografska dokumentacija območja.

\section{Kamnita struktura I}

- parc. št. Iso4 k.o. Dvori nad Izolo

Kamnita struktura I, ki je sestavni del našega preučevanja, je ležala ob vzhodnem robu parcelne meje, oblikovana nepravilno podolgovato v smeri vzhod - zahod. Njen južni rob je bil bolj strm kot severni, proti zahodu se je spuščala bolj blago. Njena višina je na najvišjem delu presegala I m. Pred našim prihodom je bila precej zaraščena s travo in nizko podrastjo (bršljan, trnje idr.), na njenem vzhodnem delu pa se je nahajala tudi višja zarast $v$ obliki hrastov, ki ob procesu dokumentiranja ni bila odstranjena. Na vrhu strukture so bili kamni precej razrahljani in poraščeni z mahom, prostor med njimi pa prazen oziroma zapolnjen $s$ humusom, preperelo lesno maso in suhim listjem. Na njenem zahodnem in severnem delu je kamnito strukturo v večji meri zaraščala trava (sl. 17a, b).

Po postopku čiščenja je bilo dokumentirano stanje, kot sledi. Kamnita struktura I (groblja) je bila velika $15,54 \times 7,6 \mathrm{~m}$. Sestavljena je bila iz nevezanih lomljencev in kamnov peščenjaka ter fliša. Podrobno je bil dokumentiran le njen vidni del, sta pa bili na območju v povezavi z njo dokumentirani kamnito vsaj še dve manjši groblji kamenja, ki kažeta na to, da se struktura nadaljuje tudi pod današnjo travnato ruši (( $\mathrm{SE} 2$ in $\mathrm{SE}$ $4 \mathrm{v}$ testni sondi I ). Zunanje mere vseh zaznanih elementov kamnite strukture znašajo I8,9 x I2,7 $\mathrm{m}$. Kamnita struktura najverjetneje ni nastala ob enkratnem procesu, ampak je povsem možno, da sta obe manjši groblji, SV od dokumentirane, nastali kot posledica primarne destrukcije kamnite strukture I. Na celotni površini kamnite strukture ni bilo najti takorekoč nikakršnih arheoloških najdb, izjemo je predstavljal primerek ostenja rimskodobne transportne posode Gss.

\section{Kamnita struktura 2}

- parc. śt. I504/k.o. Dvori nad Izolo

Kamnita struktura 2 je ležala severno od strukture $\mathrm{I}$ in od testne sonde $\mathrm{I}$, ob parcelni meji $s$ 


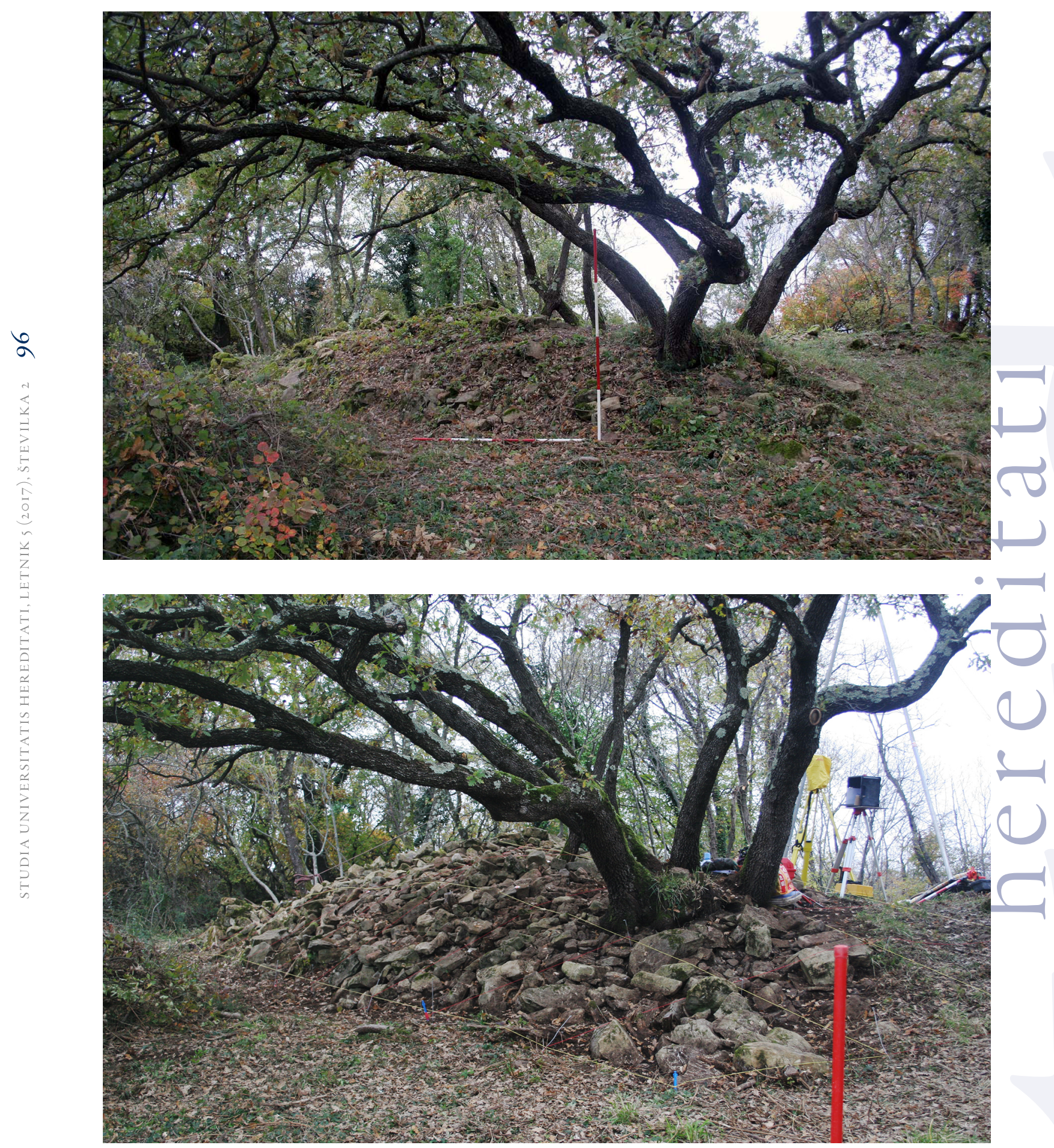

Slika 17. Kaštelir na Kortami, kamnita struktura I, pred čiščenjem (a) in po čiščenju (b) (foto: A. Ogorelec, arhiv IAD UP FHŠ). 

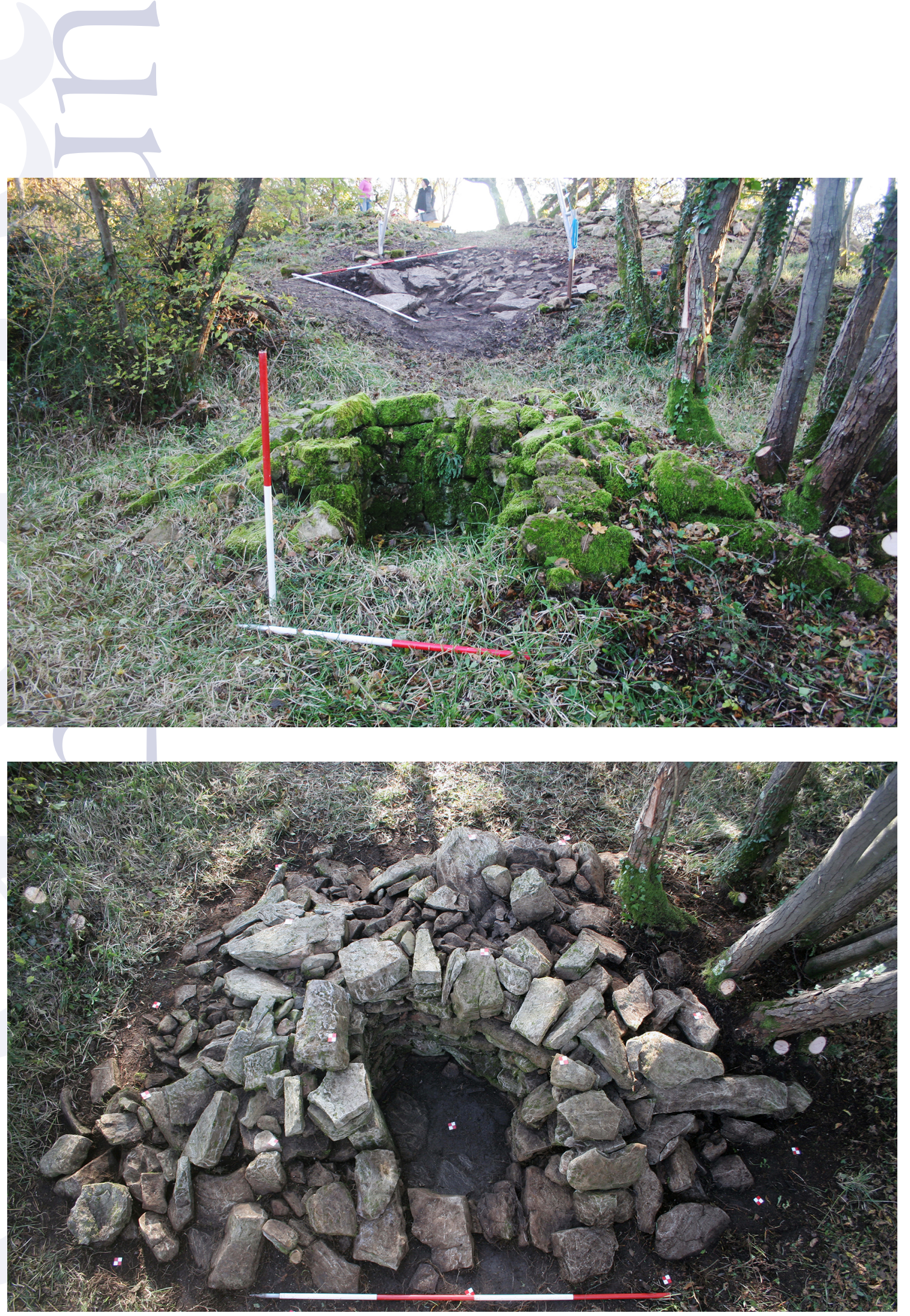

Slika 18. Kaštelir na Kortami, kamnita struktura 2, pred čiščenjem (a) in po čiščenju (b) (foto: A. Ogorelec, arhiv IAD UP FHŠ). 
parcelo parc. št. I50s k.o. Dvori nad Izolo. Pred čiščenjem je bila povsem zarasla s travo in nižjim rastjem ter prekrita $\mathrm{z}$ mahom. Struktura je bila na zahodnem delu precej poškodovana $\mathrm{z}$ višjim rastjem (sl. ı $8 \mathrm{a}, \mathrm{b})$.

Po postopku čiščenja se je pokazalo, da je kamnita struktura 2 velika 4,5 × 2,9 $\mathrm{m}$ in sestavljena iz nevezanih lomljencev ter kamnov peščenjaka, ki so $\mathrm{v}$ glavnem ležali $\mathrm{v}$ njeni ruševina. Nekateri deli strukture so verjetno obdržali še originalno gradnjo iz suhozida kot npr. notranji prostor in jugozahodni vogal strukture zidan na fronto. Struktura je imela oblikovan tudi notranji prostor, ki je na zahodni strani zalomljen in oblikovan v neke vrste vhod oziroma odprtino. Dokumentirana velikost je bila o,9 x o,63 $\mathrm{m}$. Začetek vhoda je bil zamejen z večjim, pokonci stoječim blokom kamenja, na nasprotni strani pa z zamikom ovalno-polkrožne stene. V osrednjem delu prostora je bila evidentirana humusna plast zelo temno sivega humusa s drobci oglja, odlomki rimskodobne keramike in odlomkom stekla. V severozahodnem delu prostora pa je bila odkrita zaplata temno sive gline, pod humusom pa so se na jugovzhodnem delu nahajale še kamnite plošče, ki verjetno predstavljajo tlakovanje notranjega prostora.

Kamnita struktura 2 je zanimiva predvsem zato, ker se so po njenem čiščenju pokazali posamezni elementi, ki izkazujejo njeno namensko gradnjo. Vidne so bili deli originalne gradnje objekta, kot npr. polkrožno grajen notranji del, vogalni kamni zunanjega zidu itd. Najdb je bilo v njej malo, le odlomek antičnega stekla v sekundarni legi, ki pa ne zadošča potrditev domneve, da je kamnita struktura 2, ravno tako kot kamnita srtruktura I, nastala rimskem obdobju.

\section{Sklep}

Arheološko testno sondiranje na Kaštelirju nad Kortami pri Izoli je bilo načrtovano in izvedeno z namenom, da bi se evidentirala stratifikacija arheoloških ostalin na tistemu delu najdišča, kjer se v preteklosti ni intenzivno kmetovalo. $S$ pomočjo relativnih stratigrafskih odnosov pa smo želeli natančneje definirati čas nastanka kamnitih struktur na vrhu platoja.

Testna sondiranja so ponudila zelo zanimive in hkrati presenetljive rezultate. Presenetljivi so predvsem zaradi tega, ker smo z izborom lokacije sonde predvidevali, da bomo odkrili sosledje ohranjenih prazgodovinskih plasti in ostalin, kot je bilo to zaznano pri raziskavah na južnem delu platoja v letih med 2008 in 2010 . Izkazalo pa se je, da so na tem delu najdišča ohranjene samo sledi antične poselitve, redke prazgodovinske najdbe pa so se nahajale le $\mathrm{v}$ sekundarnem kontekstu rimskodobnih ruševinskih in kulturnih plasti. Posamezni odlomki prazgodovinske keramike, ki so bili odkriti v sekundarnem kontekstu, lahko kažejo bodisi na uporabo prostora $\mathrm{v}$ prazgodovinskem času ali pa na dejstvo, da so rimskodobne aktivnosti prazgodovinske ostaline povsem uničile. Ravno tako presenetljivo pa je tudi dejstvo, da na prostoru raziskav nismo zaznali nikakršnih posegov v geološko osnovo.

Testna sondiranja ter čiščenje in dokumentiranje kamnite strukture so pokazali, da je bila le-ta grajena oziroma zamejena namensko z večjimi kamnitimi ploščami po obodu. Najprej je bila izgrajena notranjost, kasneje pa ji je bil dodan zunanji venec, sestavljen iz velikih kamnitih plošč. Na ta način je bila grajena kamnita struktura, raziskana v letu 2009. Začetek njenega nastajanja je sicer težko natančneje precizirati, vendar pa stratigrafska situacija in sosledje ruševinskih plasti $\mathrm{v}$ testni sondi ponujata dve možni interpretaciji. Najverjetneje je velika kamnita struktura na parc. št. I504 k.o. Dvori nad Izolo začela nastajati v rimskem času. $\mathrm{Ne}$ sicer v njegovem zgodnjem odseku, saj se pod samo kamnito strukturo in pa ob njej nahajajo rimska ruševinska in rimska kulturna plast, katerima lahko pripišemo zgodnejši nastanek, ampak v kasnejših obdobjih antike. Druga možna interpretacija pa bi bila, da so kamnite strukture dejansko nastale kasneje (npr. v srednjem veku) in so pri tem povsem uničile rimske ostaline. Slednja interpretacija je sicer manj verjetna, ker med drobnim arheološkim gradivom, najdb kasnejših časovnih obdobij skoraj da ni. Kar pa seve- 
da ne pomeni, da kamnita struktura I ni bila uporabljana tudi v kasnejših obdobjih zgodovine.

\section{Povzetek}

Kaštelir nad Kortami pri Izoli je ena od najbolje poznanih prazgodovinskih naselbin v slovenskem delu Istre. Najdišče je prvi omenjal Pietro Coppo v i6. stoletju, na začetku 20. stoletja ga je Carlo Marchesetti označil kot »Il castelliere d'Albuzzano presso Corte d'Isola«, prve sistematične arheološke raziskave pa so na najdišču potekale v sredini 20 . stoletja.

Med 2008 and 2014 je Kaštelir nad Kortami postal glavni poudarek projekta „Kaštelir nad Kortami - Kulturno-rekreacijski part", ki ga je finančno podpirala Občina Izola, izvajal pa Inštitut za dediščino Sredozemlja Univerze na Primorskem.

Vse dosedanje raziskave na Kaštelirju so razkrile izjemen pomen najdišča kot prazgodovinske naselbine. Osrednji prostor platoja je bil naseljen vsaj od poznega neolitika dalje, pa do rimskega obdobja, medtem ko so se v spodnjem delu ohranili naselbinski ostanki iz časa bronaste, železne in rimske dobe. Med prazgodovinskim gradivom prevladuje lončenina. Najdbe, kot so apulijski krater, estenska keramika, figurica bronastega psa, odlomki fibul, jantarna jagoda pa nakazujejo na pomembno vlogo te naselbine zlasti v času razvite železne dobe.

V decembru 2014 je Inštitut za dediščino Sredozemlja Univerze na Primorskem v sodelovanju s Pokrajinskim muzejem Koper izvedel arheološko testno sondiranje, s katerim je pridobili boljši vpogled $\mathrm{v}$ arheološko stratifikacijo plasti na osrednjem platoju gradišča. Ohranjenost plasti naj bi bila na tem delu največja, saj prostor v preteklih desetletjih ni bil povržen intenzivnemu kmetovanju.

Sonda, velikosti 4 x 4 m, je bila locirana ob vznožju kamnite strukture/groblje I na parc. št. I504 k.o. Dvori nad Izolo. Sondiranje je pokazalo, da so se na tem delu najdišča ohranile le ostaline rimskodobne poselitve prostora. Prazgodovinske najdbe so bile izjemno redke in $\mathrm{v}$ sekundarni legi. Sosledje plasti razkriva, da se je nad geološko osnovo odložila rimskodobna plast SE I4, v kateri so bili odkriti odlomki zgodnjerimske namizne keramike s črnim premazom, ki zastopana s sedmimi odlomki. Tovrstna keramika je razprostranjena po celotni obali (npr. Sermin, Fornače, Piran, Pulj, Pomljan, Simonov zaliv idr.) ter je v uporabi od 4. (zahodno Sredozemlje in Italija) do začetka I. stoletja pr. n. št. Nad njo sta se odložili rimskodobni ruševinski plasti SE I6 in SE I3, ki sta si po strukturi in sestavi precej podobni, zaradi česar sklepamo, da sta posledica istega procesa propadanja. $\mathrm{Nad}$ njimi se je formirala kamnita struktura/groblja I, katero prekrivajo še druge ruševinske plasti z rimskodobnimi najdbami, zaradi česar sklepamo, da lahko začetek nastajanja vsaj nekaterih kamnitih struktur na centralnem platoju Kaštelirja postavimo v čas rimske naselitve regije.

Kaštelir nad Kortami je izjemna prazgodovinska naselbinska točka, ampak je pa tudi prostor zgodnje rimske poselitve, ki je zaradi svoje geostrateške lege igrala pomembno vlogo pri zgodnji romanizaciji širšega območja.

\section{Summary}

Kaštelir above Korte near Izola is one of the largest and best known prehistoric settlements in the Slovenian part of Istria. The site was first mentioned by Pietro Coppo in the $16^{\text {th }}$ century. At the beginning of $20^{\text {th }}$ century Carlo Marchesetti described the site as Il castelliere d'Albuzzano presso Corte d'Isola, first systematic archaeological excavation, however took place in mid-20. Century.

Kaštelir has been a main focus of the project "Kaštelir above Korte - Cultural and recreational park", financially supported by the Municipality of Izola and conducted by the Institute for Mediterranean Heritage of University of Primorska between 2008 and 2014.

All previous excavations revealed the particular nature and importance of the site as a prehistoric hillfort. The central plateau has been inhabited at least from late $\mathrm{Ne}$ olithic onwards till the Roman period, while in the lower part settlement remains from Bronze and Iron Age as well as from Roman period have been discovered. Ceramics has been predominant prehistoric finding, while finds such as an imported vessels, the bronze animal representation of dog, amber beads and fibulas indicate the important role of the Kaštelir in Iron Age.

In December 2014 the Institute for Mediterranean Heritage of University of Primorska, in cooperation with Koper regional museum, carried out an archaeological test probing to get the better insight into the archaeological stratification in the central plateau, where 
the archaeological deposits should be preserved at their best, since intensive farming hasn't extended in this area of the site.

The trench ( $4 \times 4 \mathrm{~m}$ ), has been located in the foothill of stone structure I at plot 1504 (Dvori above Izola). The test probing has revealed that in this particular part of the site only remains of Roman period settlement have been preserved. Prehistoric finds have been sporadic and in the secondary position. The stratification of the layers revealed that the first layer above geological base is layer SU I4, containing seven sherds of Early Roman pottery with black slip, which has been found also at other sites in Istria. This kind of pottery has been in use from $4^{\text {th }}$ Century BC in W Mediterranean and Italy till the beginning of $\mathrm{I}^{\mathrm{st}}$ Century $\mathrm{BC}$. Above this layer a couple of rubble debris layers with similar composition, containing Roman finds, have been detected (SUI6 and SE I3), thus concluding that rubble debris layers have been the result of the same process of the decay. Above them the stone structure I has been erected, covered also by several debris layers with Roman findings.

The results of the excavation have underpinned indications of previous studies that the area of Kaštelir above Korte has been intensively used during Roman period. Pottery with black slip and fragments of amphorae of Lamboglia 2 type speak in favour of early Roman settlement, stratification of several layers of debris with exclusively finds from Roman period above the stone structure I foundation however indicate that at least some of the stone structures in the central area of Kaštelir has been erected during Roman period.

Kaštelir above Korte has been considered as prehistoric settlement of exceptional value, but it is also a place of a very early Roman settlement, which has due to its geostrategic location played a very important role in the Romanization of a broader region.

\section{Literatura}

Boltin, Elica. "Arheološke najdbe na Kaštelirju nad Kortami." Arheološki vestnik 9-10/3-4 (1958-59): 237-250.

Boltin, Elica. "Kaštelir nad Kortami." Varstvo spomenikov 7 (1958-59): 279.

Boltin, Elica. "Kaštelir nad Kortami.“ Varstvo spomenikov 7 (1958-59): 293.
Cipriano, Silvia in Francesca Ferrarini. Le amfore romane di Opitergium. Cornuda. Oderzo: Lions club di Oderzo, 200I.

Horvat, Jana in Alma Bavdek. Okra. Vrata med Sredozemljem in Srednjo Evropo. Opera Instituti Archaeologici Sloveniae 17. Ljubljana: ZRC SAZU, 2009.

Marchesetti, Carlo. I castellieri preistorici di Trieste e della regione Giulia. Trieste: Museo civico di Storia naturale, 1903.

Plestenjak, Ana, ur. Sermin, Arheološke raziskave v letu 2010. Ljubljana: Arhej d.o.o, 2012.

Sakara Sučević, Maša. Prazgodovinska keramika med Miljskim zalivom in porečjem Mirne. Koper: Fakulteta za humanistične študije, Univerza na Primorskem (doktorska disertacija neobjavljeno gradivo), 2012.

Sakara Sučević, Maša, Preložnik, Andrej in Aleš Ogorelec. Preliminarno poročilo o zašcitnih arheoloških raziskavah na Kaštelirju nad Kortami, parc. št. I7o6, k.o. Dvori nad Izolo 2.4.-21.4.2010. Koper: Univerza na Primorskem, Znanstvenoraziskovalno središče, Inštitut za dediščino Sredozemlja, 2 оıо.

Tomaž, Alenka in Maša Sakara Sučević. Kaštelir nad Kortami - historična analiza prostora (elaborat). Koper: Inštitut za dediščino Sredozemlja, Znanstvenoraziskovalno središče, Univerza na Primorskem, 2014.

Vidrih Perko, Verena. "Amfore v Sloveniji.“ Annales, Ser. hist. sociol. Io, št. 2 (22)

(2000): 42I-456.
○
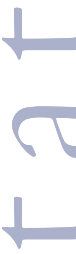

ras
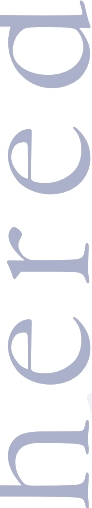



\section{NAVODILA ZA AVTORJE}

Revija objavlja primarno v slovenskem jeziku, toda tudi v večjih svetovnih jezikih (angleščina, nemščina, francoščina, italijanščina, ruščina). V objavo se sprejmejo tudi članki v cirilici. V primeru tujejezičnega članka morata biti izvleček in povzetek poleg angleščine obvezno v slovenskem jeziku. Za oboje poskrbi avtor.

Članek (praviloma v obsegu 7000 , vendar največ 10.000 besed) naj ima na začetku: 1) naslov ter ime in priimek avtorja/-ice; 2) izvleček v slovenskem in abstract angleškem jeziku, do 250 besed; 3 ) ključne besede v slovenščini in angleščini (do 5); 4) kratko predstavitev avtorja/-ice (do roo besed v slovenščini in angleščini), navedena naj bo tudi organizacija zaposlitve. Članek naj po razpravnem besedilu vsebuje še: I) povzetek v slovenščini in angleščini ter 2) seznam virov in literature.

Prispevki naj bodo napisani v knjižni slovenščini (ali v knjižni različ̌ici katerega tujih jezikov, v kolikor gre za tujejezično delo) ob upoštevanju veljavnega pravopisa, v nasprotnem primeru si uredništvo pridržuje pravico, da članka ne recenzira oziroma ga zavrne.

Če je prispevek že bil objavljen v kaki drugi reviji ali če čaka na objavo, je treba to izrecno navesti.

Prispevek naj ima dvojni medvrstični razmik, tip črk naj bo Times New Roman, velikost 12 pik (v opombah 10). Besedilo naj bo levo poravnano, strani pa zaporedno oštevilčene. Odstavki naj bodo ločeni s prazno vistico.

Uporabiti je mogoče do tri hierarhične nivoje podnaslovov, ki naj bodo ośtevilčeni (uporabljajte izključno navaden $s l o g$, v prelomu bodo ravni ločene tipografsko): I. - I.I - I.I.I

Za poudarke uporabite izključno ležeći tisk(v primeru jezikoslovnih besedil, kjer so primeri pravilomavležečem tisku, lahkoza poudarke izjemoma uporabite polkrepki tisk). Ležeče pišite tudi besede v tujih jezikih. Raba drugih tipografskih rezov (podčrtano, velike male črke, krepko kurzivno ...) ni dovoljena. Ne uporabljajte dvojnih presledkov, prav tako ne uporabljajte preslednice za poravnavo besedila. Edina oblika odstavka, ki je dovoljena, je odstavek z levo poravnavo brez rabe tabulatorjev prve ali katerekoli druge vrstice v ostavku (ne uporabljajte sredinske, obojestranske ali desne poravnave odstavkov). Oglate oklepaje uporabljajte izključno za fonetične zapise oz. zapise izgovarjave. Tri pike so stične le, če označujejo prekinjeno bese... Pri nedokončani misli so tri pike nestične in nedeljive ... Prosimo, da izključite funkcijo deljenja besed.

Sprotne opombe naj bodo samooštevilčene (številke so levostično za besedo ali ločilom - če besedi, na katero se opomba nanaša, sledi ločilo) in uvrščene na tekočo stran besedila.

Citati v besedilu naj bodo označeni z dvojnimi (» «), citati znotraj citatov pa z enojnimi (") narekovaji. Izpuste iz citatov in prilagoditve označite s tropičjem znotraj poševnic /.../. Daljše citate (več kot s vrstic) izločite v samostojne odstavke, ki jih od ostalega besedila ločite $\mathrm{z}$ izpustom vrstice in umikom $\mathrm{v}$ desno. Vir citata označite $\mathrm{v}$ okroglem oklepaju na koncu citata. Če je avtor/-ica naveden/-a v sobesedilu, priimek lahko izpustite.
V besedilu označite najprimernejša mesta za likouno opremo (tabele, slike, skice, grafikone itd.) po zgledu: [Tabela I približno tukaj]. Posamezne enote opreme priložite vsako v posebni datoteki (v.eps, ai, .tif ali .jpg formatu, minimalna resolucija $300 \mathrm{dpi}$, tabele prilagajte v posebni datotetki v formatu .doc, grafe pa v formatu .xls, kjer naj ob grafu stoji tabela, ki je podlaga za graf). Naslov tabele je nad tabelo, naslov grafa/slike pa pod grafom/sliko.

Prostor, ki ga oprema v prispevku zasede, se šteje v obseg besedila, bodisi kot 250 besed (pol strani) ali 500 besed (cela stran).

Ob oddaji preda avtor uredništvu članek v formatu .doc in hkrati tudi.pdf.

Za citiranje literature in za pripravo seznama uporabljene literature se uporablja izkljucno stil Chicago, in sicer v obliki, kot je aktualna, tj. v svoji i6. izdaji (http://www.chicagomanualofstyle.org/home.html, 16. izdaja na razpolago na zahtevo tudi pri uredniku izdaje)

I: Enoavtorska monografija

a) Polna oblika reference pod crrto: Michael Pollan, The Omnivore's Dilemma: A Natural History of Four Meals (New York: Penguin, 2006), 99-100.

b) Kratka oblika reference pod črto: Pollan, Omnivore’s Dilemma, 3 .

c) Navedba v virih in literaturi: Pollan, Michael. The Omnivore's

Dilemma: A Natural History of Four Meals. New York: Penguin, 2006. II: Većavtorska monografija

a) Polna oblika reference pod črto: Geoffrey C. Ward and Ken Burns, The War: An Intimate History, 1941-1945 (New York: Knopf, 2007), 52

b) Navedba v virih in literaturi: Ward, Geoffrey C., and Ken Burns. The War: An Intimate History, 1941-1945. New York: Knopf, 2007.

III: Knjiga z urednikom

a) Polna oblika reference pod črto: Joel Greenberg, ed., Of Prairie, Woods, and Water: Two Centuries of Chicago Nature Writing (Chicago: University of Chicago Press, 2008), 42.

b) Kratka oblika reference pod črto: Greenberg, Prairie, Woods, and Water, 326-27.

c) Navedba v virih in literature: Greenberg, Joel, ed. Of Prairie, Woods, and Water: Two Centuries of Chicago Nature Writing. Chicago: University of Chicago Press, 2008.

IV: Poglavje v knjigi

a) Polna oblika reference pod črto: Glenn Gould, "Streisand as Schwarzkopf," in The Glenn Gould Reader, ur. Tim Page (New York: Vintage, 1984),310.

b) Kratka oblika reference pod črto: Gould, "Streisand as Schwarzkopf," 309 .

c) Navedba v virih in literaturi: Gould, Glenn. "Streisand as Schwarzkopf." In The Glenn Gould Reader, ur. Tim Page, 308-11. New York: Vintage, 1984 .

Gould, "Streisand as Schwarzkopf," 309 
V: Clanek v reviji

a) Polna oblika reference pod črto: Walter Blair, "Americanized Comic Braggarts," Critical Inquiry 4, no. 2 (1977):331-32.

b) Kratka oblika reference pod črto: Blair, "Americanized Comic Braggarts," 335 .

c) Navedba v virih in literaturi: Blair, Walter. "Americanized Comic Braggarts." Critical Inquiry 4, no. 2 (1977): 331-49.

VI: Clanek v reviji (digitalna objava; DOI)

a) Polna oblika reference pod črto: William J. Novak, "The Myth of the 'Weak' American State," American Historical Review Ir3 (June 2008): 758, doi:10.1086/ahr.113.3.752.

b) Kratka oblika reference pod črto: Novak, "Myth," 770 .

c) Navedba v virih in literaturi: Novak, William J. "The Myth of the 'Weak' American State." American Historical Review 113 (June 2008): 752--72. doi:10.1086/ahr.113.3.752., "Streisand as Schwarzkopf," 309.

VII: Članek v reviji (digitalna objava, URL)

a) Polna oblika reference pod črto: Wilfried Karmaus and John F. Riebow, "Storage of Serum in Plastic and Glass Containers May Alter the Serum Concentration of Polychlorinated Biphenyls," Environmental Health Perspectives II2 (May 2004): 645, http://www. jstor.org/stable/3435987 (datum dostopa do spletne strani).

b) Navedba v virih in literaturi: Karmaus, Wilfried, and John F. Riebow. "Storage of Serum in Plastic and Glass Containers May Alter the Serum Concentration of Polychlorinated Biphenyls." Environmental Health Perspectives II2 (May 2004): 643--47. http:// www.jstor.org/stable/3435987.

O morebitnih drugih posebnostih se posvetujte z uredništvom

Naslov uredništva: dr. Gregor Pobežin, Fakulteta za humanistične študije Univerze na Primorskem, Titov trg 5,

SI-6000 Koper, gregor.pobezin@fhs.upr.si 

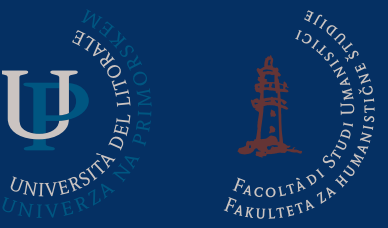

Založba Univerze na Primorskem www.hippocampus.si ISSN 2350-5443

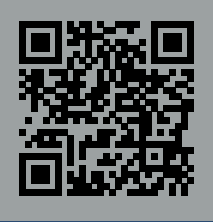

